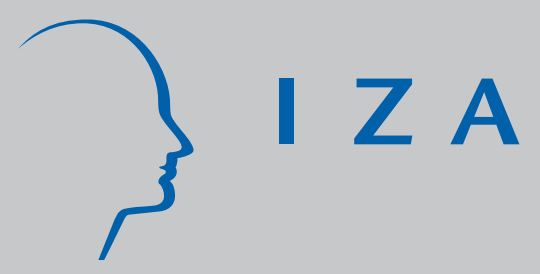

IZADP No. 2746

Barriers to Entry, Deregulation and Workplace Training

Andrea Bassanini

Giorgio Brunello

April 2007 


\title{
Barriers to Entry, Deregulation and Workplace Training
}

\author{
Andrea Bassanini \\ OECD, CEPN, University of Paris 13 \\ and ERMES, University of Paris 2 \\ Giorgio Brunello \\ University of Padova, KIER Kyoto, \\ CESifo and IZA
}
Discussion Paper No. 2746
April 2007

IZA

P.O. Box 7240

53072 Bonn

Germany

Phone: +49-228-3894-0
Fax: +49-228-3894-180
E-mail: iza@iza.org

Any opinions expressed here are those of the author(s) and not those of the institute. Research disseminated by IZA may include views on policy, but the institute itself takes no institutional policy positions.

The Institute for the Study of Labor (IZA) in Bonn is a local and virtual international research center and a place of communication between science, politics and business. IZA is an independent nonprofit company supported by Deutsche Post World Net. The center is associated with the University of Bonn and offers a stimulating research environment through its research networks, research support, and visitors and doctoral programs. IZA engages in (i) original and internationally competitive research in all fields of labor economics, (ii) development of policy concepts, and (iii) dissemination of research results and concepts to the interested public.

IZA Discussion Papers often represent preliminary work and are circulated to encourage discussion. Citation of such a paper should account for its provisional character. A revised version may be available directly from the author. 


\section{ABSTRACT \\ Barriers to Entry, Deregulation and Workplace Training*}

We develop a theoretical and empirical analysis of the impact of barriers to entry on workplace training. Our theoretical model yields ambiguous predictions on the sign of this relationship. On the one hand, given the number of firms, a deregulation reduces profits per unit of output, and thereby reduces training. On the other hand, the number of firms increases, and so does the output gain from training, which facilitates the investment in training. Our numerical simulation shows that for reasonable values of the parameters a negative relationship prevails. We use repeated cross section data from the European Labour Force Survey to investigate empirically the relationship between product market regulation and training incidence in a sample of 15 European countries and 13 industrial sectors, which we follow for about 7 years. Our empirical results are unambiguous and show that an increase in product market deregulation generates a sizeable increase in training incidence.

JEL Classification: J24, L11

Keywords: training, product market competition, Europe

Corresponding author:

Giorgio Brunello

Department of Economics

University of Padova

via del Santo 33

35100 Padova

Italy

E-mail: giorgio.brunello@unipd.it

\footnotetext{
* The views expressed here cannot be attributed to the OECD or its member countries. We are grateful to Kenn Ariga, Maria De Paola, Alfonso Rosolia, Francisco Serranito, Said Souam and to the audiences in Milan Cattolica and Paris 13 (CEPN) for comments. The usual disclaimer applies.
} 


\section{Introduction}

Product and labour market deregulation have attracted considerable attention by economists and policy makers, and there is a broad concern that these regulations can hamper growth and increase unemployment (see Blanchard and Giavazzi, 2003, Alesina et al, 2005). Empirical research on the economic effects of product market regulation and deregulation has focused so far on employment (Kugler and Pica, 2004), productivity growth (Nicoletti and Scarpetta, 2003, Aghion et al. 2006), investment in capital stock (Alesina et al, 2005), innovation (Aghion et al., 2005), and easiness to start a business (Djankov et al, 2001).

This paper investigates the relationship between product market regulation / deregulation and training, which we define as the accumulation of human capital taking place in firms after school completion. Looking at training is important because the accumulation of skills is perceived as one of the main factors affecting productivity growth (see e.g. OECD, 2007). The literature in this area is small but with controversial results. Some theoretical research suggests that deregulation can be bad for training. Gersbach and Schmutzler, 2003 and 2005, for instance, argue that more intensive competition in the product market reduces training incidence, especially when the country is large. The idea is that a larger number of competitors increases the risk of poaching, which discourages employers from training. However, when the increase in competition affects the physical proximity of workers and firms, the negative impact of the risk of poaching on training can be compensated by the positive local agglomeration effects. Brunello and De Paola, 2007, show that in this case the relationship between product market competition and training cannot be signed a priori.

The work by Acemoglu and Pischke, 1999, on training in imperfect labour markets can also have implications for the relationship of interest: since deregulation reduces rents, it might reduce the employer's incentive to invest in general training. In contrast, Autor, 2001, provides a model showing that training can increase with product market competition. By focusing on temporary help firms, he shows that training is a tool to improve the quality of service provided by firms in response to fiercer competition.

Empirical work on this issue is scarce but less controversial and points to a positive relationship between competition and training. Autor, 2001, for instance, shows that the Herfindhal index and training are negatively correlated in US temporary help firms, which suggests that less competition reduces training. In a multi-country study of Europe, which exploits cross country and time series 
variations in product market and labour market institutions, Bassanini et al, 2007, find evidence of a negative and statistically significant correlation between the index of product market regulation developed by the OECD and training intensity, thereby supporting and generalizing Autor's findings.

One potential drawback of multi-country studies is that the combination of the country and time dimensions does not allow to fully control for confounding factors which might affect training and that vary across country and over time. One way to overcome this limit is to add an additional dimension to the data, as we do in the current paper. We build on the approach followed by Bassanini et al, 2007, by adding the sector as such dimension. With data which vary by country, year and sector, we can compare a treatment group, which consists of the sectors directly affected by our measure of deregulation, with a control group, composed of those sectors which are not affected directly by such measure, while at the same time controlling for country and country by time specific effects. The assignment to sectors is random insofar as we can safely rule out the possibility that firms anticipating policy reform can switch sector of production. Given the costs of switching sector, we believe that this source of endogeneity is of second order of relevance.

We use the OECD database on product market deregulation developed by Nicoletti and Scarpetta, 2003, which has been designed to pick up regulatory reforms in traditionally heavily regulated sectors, such as transport, communication and public utilities. We consider these sectors as our treatment group, and contrast their behaviour with respect to training with the control group, which consists of the manufacturing sector, limiting our analysis to European countries. After the implementation of the single market programme in Europe in the early 1990s, we can assume that no sector-specific regulatory reform affected the manufacturing sector, which therefore qualifies as a genuine control. ${ }^{1}$ By comparing training incidence in these sectors, we try to disentangle the effects of deregulation on training from other confounding factors, which affect both groups. To do so we match regulation data with training data from the European Labour Force Survey as well as several other sector-level databases, to obtain a rich sector-level database of training co-variates.

Our evidence clearly suggests that product market deregulation increases training incidence. The estimated effects are significant, because a one point reduction in the selected measure of regulation - which ranges between 0 and 6 - is estimated to trigger a 10 percent increase in training incidence. To motivate our empirical investigation, we develop a model which casts the training decision in an economy characterized by imperfectly competitive product and labour markets, as in

\footnotetext{
${ }^{1}$ The manufacturing sector, however, could be affected indirectly, because of the close linkage among sectors typical of modern economies.
} 
Blanchard and Giavazzi (2003). We show that in equilibrium the impact of deregulation on training is ambiguous. On the one hand, a reduction in the barriers to entry for a given number of firms compresses profits per unit of output, and thereby reduces training. On the other hand, and conditional on profits per unit of output, additional firm entry due to deregulation increases the output gains from training, which facilitates investment. We interpret our empirical results as suggestive of the fact that the latter effect prevails on the former.

The paper is organized as follows. In the first section we develop the theoretical model. The subsequent sections introduce the empirical strategy and the data and present our estimates of the relationship between training and product market deregulation. Conclusions follow

\section{The Model}

Following Blanchard and Giavazzi, 2003, and Stevens, 1996, consider a two - stage model economy where each firm produces a differentiated product using labour. The number of firms $m$ is determined by an entry condition, which is affected by product market regulation. The logical sequence of the model is as follows: first of all, firms decide entry. In the first preparatory stage after entry, each firm invests in training and pays the training costs. The willingness to pay is justified either because the imparted skills are firm - specific or because labour market frictions - including search and informational asymmetries - substantially reduce the transferability of general skills from a firm to another, as discussed by Acemoglu and Pischke, $1999^{2}$. In both the decision to enter and in the choice of how many workers to train, the employer can perfectly foresee the wages she will pay in the final stage, the level of employment $L$, the prices she will be able to sell her goods at and the number of firms operating in the market. In the second and final stage, and conditional on training, firms and workers bargain over wages and employment, prices are set and production occurs.

Firms in this economy share the same production and training technology, and the same elasticity of product demand. Risk neutral workers have the same reservation wage, and there are no exogenous separations of workers from firms. We show that the equilibrium is symmetric: all firms choose the same training incidence, each product price is equal to the average price, and each trained worker receives the same wage. With symmetry, in equilibrium there is no ex-post labour mobility and

\footnotetext{
${ }^{2}$ Bassanini et al, 2007, review the evidence suggesting that firms bear most of training costs. In an economy where firms repeatedly interact and skills are only partially transferable, the gains from poaching can be more than offset by the costs, which include additional training as well as reputation costs.
} 
ex-post poaching. Firms operate the technology

$$
Y_{i}=A L_{i}^{e}
$$

where $Y$ is output, $L^{e}$ is employment in efficiency units, $A$ is the productivity of labour and the subscript $i$ is for the single firm. Labour consists of trained $\left(L_{T}\right)$ and untrained $\left(L_{U}\right)$ workers. Trained workers are skilled and untrained workers are unskilled. Since trained workers are more productive than untrained workers, employment in efficiency units is

$$
L_{i}^{e}=L_{U i}+L_{T i}
$$

where $\gamma>1$ is the relative efficiency of skilled labour ${ }^{3}$. Letting $T$ be training incidence and $L$ employment, $L_{T i}=T_{i} L_{i}$ and the production function can be written as ${ }^{4}$

$$
Y_{i}=A L_{i}\left[1+(\gamma-1) T_{i}\right]
$$

Since employment is set by bargaining in the second stage of the game, the decision on how many workers to train in the initial period is equivalent to the choice of training incidence $T$.

Define net and gross profits as net and gross of training costs. The characterization of the equilibrium proceeds by backward induction and starts with the decision concerning wages and prices. We assume that untrained workers receive the common reservation wage $V$. Trained workers, however, bargain over wages and prices with the firm. Ex-post bargaining can be justified by the fact that, when firms invest in training, workers cannot commit on ex-ante wages but re-contract after the training investment has taken place (Malcolmson, 1997). Let the wage of untrained workers be $W_{U}=V$ and the wage of trained workers be $W_{T}=W$, with $W \geq V$.

We characterize the bargaining as a cooperative Nash game, which we solve by maximizing

$$
\beta \ln \left[\left(W_{i}-V\right) T_{i} L_{i}\right]+(1-\beta) \ln \left\{P_{i} Y_{i}-L_{i}\left(W_{i} T_{i}+V\left(1-T_{i}\right)\right)\right\}
$$

\footnotetext{
${ }^{3}$ Total employment is instead defined as $L_{i}=L_{U i}+L_{T i}$.

${ }^{4}$ See Dearden, Reed and Van Reenen, 2006.
} 
with respect to wages and employment. This is equivalent to assuming that the parties are involved in efficient bargaining. An alternative characterization would be the "right to manage" model, where the employer retains authority over employment determination. We follow Blanchard and Giavazzi in the preference for efficient bargaining, which they argue has the advantage of capturing the possibility that firms are not operating on their demand for labour. However, we show in the Appendix that our key qualitative results are not affected if we were to choose the right to manage model.

In [4] the element in brackets is the gain from a positive settlement accruing to trained workers, who have linear utility functions. This gain is weighted with the relative bargaining power of skilled labour, $\beta$. By definition, unskilled workers do not gain from the bargain, and are bound to their reservation wages. The element in braces is the gross nominal profit from a positive settlement accruing to the employer ${ }^{5}$. We assume that profits in the event of failure to settle are equal to zero.

Notice that employment setting is equivalent to price setting, because labour demand is a derived demand and each firm faces the following product demand function

$$
Y_{i}=\frac{Y}{m}\left(\frac{P_{i}}{P}\right)^{-\theta}
$$

where $\theta=\sigma g(m)>1, \sigma$ is a suitable constant and $g^{\prime}>0, Y$ is aggregate output, and $P_{i}$ and $P$ are the price of product $i$ and the average price. Following Blanchard and Giavazzi, 2003, the absolute value of the elasticity of demand with respect to the relative price $\theta$ is increasing in the number of firms. This follows from the fact that an increase in the number of products associated to entry raises the elasticity of substitution between products.

The outcome of the bargain is

$$
\begin{aligned}
& T_{i} W_{i}=\beta P_{i} A\left[1+(\gamma-1) T_{i}\right]+V\left(T_{i}-\beta\right) \\
& \frac{P_{i} A\left[1+(\gamma-1) T_{i}\right]}{\left[W_{i} T_{i}+V\left(1-T_{i}\right)\right]}=\frac{\theta}{\theta+\beta-1}
\end{aligned}
$$

\footnotetext{
${ }^{5}$ Profits are gross because training costs in the second stage are bygones.
} 
The former condition can also be written in a more familiar way as $W_{i}=V+\frac{\beta}{T_{i}}\left(\frac{P_{i} Y_{i}}{L_{i}}-V T_{i}\right)$. The right hand side of the latter condition is the price cost margin $\Lambda$, where the costs are net of training costs. Simple manipulation of these two conditions yields ${ }^{6}$

$$
\frac{P_{i}}{P}=\frac{\theta}{\theta-1} \frac{V}{P A\left[1+(\gamma-1) T_{i}\right]}
$$

We next turn to the initial preparatory period, when employers decide how many workers to train. Let the cost of training per employee be

$$
c\left(T_{i}\right)=\frac{\mu T_{i}^{2}}{2}
$$

a convex increasing function of training incidence. This assumption captures decreasing returns in the production of human capital and rules out corner solutions for optimal training incidence. Using [5] and [6a] in the definition of net real profits $\Pi{ }^{7}$ we obtain

$$
\Pi_{i}=\left\{\frac{1-\beta}{\theta-1} \frac{V}{P A\left(1+(\gamma-1) T_{i}\right)}-\frac{\mu T_{i}^{2}}{2 A\left(1+(\gamma-1) T_{i}\right)}\right\} \frac{Y}{m}\left(\frac{\theta}{\theta-1}\right)^{-\theta}\left(\frac{V}{P}\right)^{-\theta}\left[A\left(1+(\gamma-1) T_{i}\right)\right]^{\theta}
$$

The term in braces on the right-hand side represents net real profits per unit of output $\pi_{i}$, while the product of all the other terms on the right-hand side represents output $Y_{i}$. The marginal variation of real profits as a result of additional training is given by

$$
\frac{\partial \Pi_{i}}{\partial T_{i}}=Y_{i} \frac{\partial \pi_{i}}{\partial T_{i}}+\pi_{i} \frac{\partial Y_{i}}{\partial T_{i}}=Y_{i}\left[\frac{\left(-\mu T_{i}\right)}{A\left(1+(\gamma-1) T_{i}\right)}-\frac{(\gamma-1) \pi_{i}}{\left(1+(\gamma-1) T_{i}\right)}\right]+\pi_{i} \frac{\theta(\gamma-1) Y_{i}}{\left(1+(\gamma-1) T_{i}\right)}
$$

\footnotetext{
${ }^{6}$ Employment is given by $L_{i}=\frac{Y_{i}}{A\left[1+(\gamma-1) T_{i}\right]}=\frac{Y}{m} \frac{1}{A\left[1+(\gamma-1) T_{i}\right]}\left(\frac{P_{i}}{P}\right)^{-\theta}$

${ }^{7}$ That is, nominal profits divided by the average price.
} 
The first-order condition for a maximum with respect to $T_{i}\left(\partial \Pi_{i} / \partial T_{i}=0\right)$ yields $^{8}$

$$
(\theta-1) A(\gamma-1) \pi_{i}=\mu T_{i}
$$

Training is increasing in net real profits per unit of output $\pi_{i}$ and, conditional on $\pi_{i}$, is decreasing in training costs $\mu$ and increasing in the difference between the productivity of skilled and unskilled workers $A(\gamma-1)$ as well as in the elasticity of substitution $\theta$. The latter effect comes from the fact that output gains from training are increasing in $\theta$ - see the last term on the right hand side of Eq.10. Substituting out $\pi_{i}$ in [11] with its expression in terms of $\mathrm{T}, \mathrm{V}$ and other parameters we obtain

$$
T_{i}^{*}=\frac{-\mu \pm \sqrt{\mu^{2}+4 \mu(\gamma-1)^{2} \frac{V}{P}(1-\beta) \frac{1+\theta}{2}}}{\mu(\gamma-1)(1+\theta)}>0
$$

Notice that [12] yields a unique positive solution. Since both $V$ and the parameters $\gamma, \theta, \mu$ and $\beta$ do not vary across firms, it must be that $T_{i}^{*}=T^{*}$, implying that all firms invest in the same training incidence. By implication, equation [7] suggests that at the optimal level of training firms have the same relative price. Since in general equilibrium we cannot have that all firms have a relative price above or below 1 (see Blanchard and Giavazzi, 2003), it must be that $\frac{P_{i}}{P}$ is equal to 1 , which implies

$$
\frac{V}{P}=\frac{\theta-1}{\theta} A[1+(\gamma-1) T]
$$

where we drop hereafter the subscript $i$. Using [13], [5] and [6a] in the definition of profits, and imposing the general equilibrium condition on prices, the equilibrium number of firms is determined by the condition that net profits per unit of output $\pi$ must be equal to the cost of entry per unit of output $\rho$

\footnotetext{
${ }^{8}$ The second order conditions for a maximum hold.
} 


$$
\pi=\frac{1-\beta}{\theta}-\frac{\mu T^{2}}{2 A[1+(\gamma-1) T]}=\rho
$$

where $\frac{1-\beta}{\theta}=\frac{\Lambda-1}{\Lambda}$ is gross real profits per unit of output, and $\frac{\partial \Lambda}{\partial \rho}>0$. A reduction in $\rho$ corresponds to product market deregulation and lower barriers to entry. Conditional on training, a deregulation increases the number of firms and $\theta$. As a consequence, profits per unit of output fall until the arbitrage condition [14] is satisfied. Blanchard and Giavazzi, 2003, use a similar convenient specification for the cost of entry. In the Appendix we show that our results still hold when we specify more conventionally the cost of entry as a fixed cost, rather than as a cost proportional to output.

Using [14] into [11] to eliminate profits per unit of output we obtain

$$
\mu T=(\theta-1) A(\gamma-1) \rho
$$

Equations [14] and [15] describe two schedules in the $(T, \theta)$ plane: the schedule TT associated to [15] implies a positive relationship between training incidence and the number of firms ${ }^{9}$ (see Figure 1). The reason is that, conditional on net profits per unit of output, the output gains from training are larger the larger the elasticity of substitution between products (see eq. [11]). On the other hand, the schedule MM associated to [14] suggests a negative relationship. Conditional on net profits per unit of output, the greater the training, the greater the gross profits that are required to avoid losses. In turn, this implies that, if net profits are fixed by entry barriers, the greater the training the smaller the number of firms that can survive in equilibrium without making losses.

\footnotetext{
${ }^{9}$ Recall that $\frac{\partial \theta}{\partial m}=\sigma g^{\prime}(m)>0$.
} 


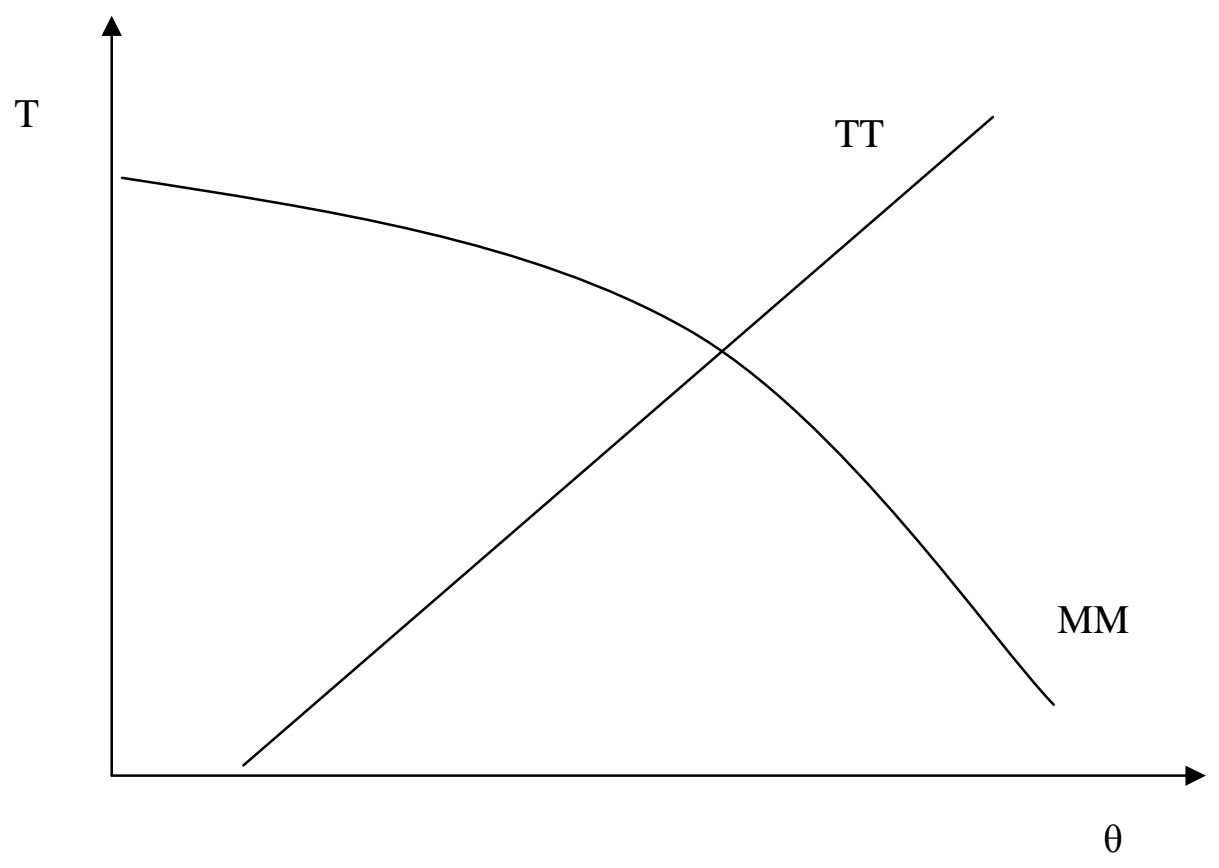

Figure 1: The relationship between $\theta$ and $T$

We establish the following

Lemma. The equilibrium exists and is unique if $\rho \leq 1-\beta$.

Proof: equations [14] and [15] describe two schedules in the $(T, \theta)$ plane: the schedule TT associated to [15] has a positive slope and the schedule MM associated to [14] has a negative slope. Moreover, training incidence tends to zero as $\theta \rightarrow 1$ in [15] and if $\rho \leq 1-\beta$ to a non-negative number in [14]. Therefore, the two schedules intersect in the relevant domain of the two variables, and their intersection is unique.

QED

Proposition. A deregulation of the product market - which corresponds to a reduction in the parameter $\rho$ - increases training incidence if 


$$
\frac{1-\beta}{\theta(\rho)} \frac{\theta(\rho)-1}{\theta(\rho)}<\rho \leq \frac{1-\beta}{\theta(\rho)}
$$

and reduces training incidence if

$$
0<\rho<\frac{1-\beta}{\theta(\rho)} \frac{\theta(\rho)-1}{\theta(\rho)}
$$

Proof: total differentiation of [14] and [15] yields

$$
\begin{aligned}
& \Sigma_{1} d m+\Sigma_{2} d T=\Sigma_{5} d \rho \\
& \Sigma_{3} d m+\Sigma_{4} d T=\Sigma_{6} d \rho
\end{aligned}
$$

where

$$
\begin{array}{ll}
\Sigma_{1}=\sigma g^{\prime}(m)(\gamma-1) \rho A \quad \Sigma_{2}=-\mu & \Sigma_{3}=-\frac{1-\beta}{\sigma g(m)^{2}} g^{\prime}(m) \quad \Sigma_{4}=-\frac{2 \mu T+\mu T^{2}(\gamma-1)}{2 A[1+(\gamma-1) T]^{2}} \\
\Sigma_{5}=-(\sigma g(m)-1)(\gamma-1) A & \Sigma_{6}=1
\end{array}
$$

Since the determinant of the Jacobian is negative when $\theta<+\infty$ and $\rho>0, \frac{d T}{d \rho}<0$ if $\Sigma_{1} \Sigma_{6}-\Sigma_{3} \Sigma_{5}>0$, or

$$
\frac{1-\beta}{\theta(\rho)} \frac{\theta(\rho)-1}{\theta(\rho)}<\rho
$$

Non-negative profits also imply - see [15] - that $\rho \leq \frac{1-\beta}{\theta(\rho)}$. Therefore $\frac{d T}{d \rho}<0$ if

$$
\frac{1-\beta}{\theta(\rho)} \frac{\theta(\rho)-1}{\theta(\rho)}<\rho \leq \frac{1-\beta}{\theta(\rho)}
$$

Clearly, $\frac{d T}{d \rho}>0$ if $\frac{1-\beta}{\theta(\rho)} \frac{\theta(\rho)-1}{\theta(\rho)}>\rho$.

QED

We also establish the following corollary

Corollary. A deregulation of the product market increases the number of firms $\mathrm{m}$.

Proof. Follows from the proof above and from the fact that $\Sigma_{5} \Sigma_{4}-\Sigma_{2} \Sigma_{6}>0$.

In other words, condition [16] is less likely to hold when deregulation starts from a very low value of $\rho$ or the product market is close to perfect competition $(\theta \rightarrow \infty)$. However, for reasonable values of the parameters condition [16] holds even for relatively low values of $\rho$. To illustrate this 
numerically, we set the configuration of parameters so as to obtain that when the ratio of the measure of barriers to entry to its maximum possible value $(1-\beta)$ is equal to the observed median ratio, in the sample for which we have training and regulation data (see next section), we obtain approximately an optimum training incidence equal to the observed median training incidence. ${ }^{10}$ This ratio is equal to 0.62 according to our indicators. Assuming $\mu=0.1, \gamma=1.2, \beta=0.5$ and $A=1$ (see the Appendix for the justification of these choices), for $\rho=0.31(0.62 * 0.5)$ we obtain that optimal training incidence is equal to $36,1 \%$, not far from the median level that we observe in our data (38,9\%). With these parameters, a deregulation which cuts $\rho$ increases training so far as $\rho>0.077$ (see Figure 1), a low threshold, which has rarely been attained in historical perspective, and corresponds only to about $7 \%$ of the observations for which we have data. Even more, $\frac{\partial T}{\partial \rho} \cong 0$ in a relatively large region, and it starts getting significantly greater than zero only for $\rho<0.03$, a value that corresponds to less than $3 \%$ of the observations for which we have data. Conversely, for values above $\rho=0.2$, which corresponds approximately to the first quartile in our data, the relationship between barriers to entry and training stocks is negative and approximately linear.

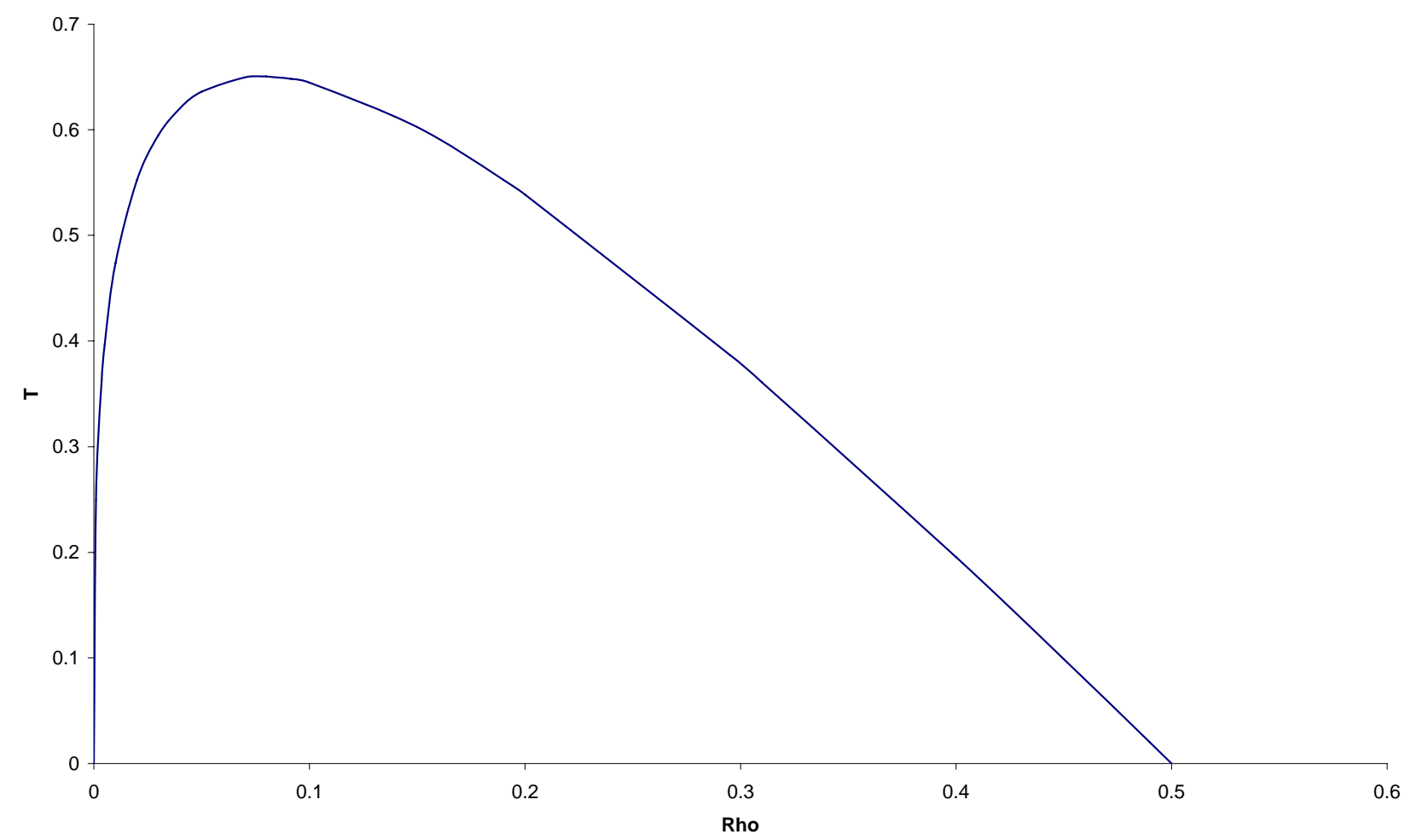

Figure 2: The relationship between $\rho$ and $T$ with the selected configuration of parameter values.

\footnotetext{
${ }^{10}$ Where training incidence is defined in terms of the stock of training (see next section for the method of calculation).
} 
The effect of product market deregulation on training incidence is illustrated in Figure 3, where continuous lines refer to the initial equilibrium and dashed lines to the new equilibrium. While the effect of deregulation on the number of firms is not ambiguous, the effect on training depends on the relative shift of the two curves. Taking as given the amount of training of each firm, a reduction in the barriers to entry increases the number of firms, thereby shifting the MM schedule outwards - see equation [14]. This, in turn, increases training incidence along the TT schedule since, conditional on net profits, output gains from training are greater - see equations [10], [11] and [15]. However, for a given number of firms, lower entry barriers also rotate the TT schedule downwards, ${ }^{11}$ because they reduce net profits per unit of output and the net gains from training - see equations [10] and [15]. The overall effect on $T$ is ambiguous, but is positive if condition [16] holds.

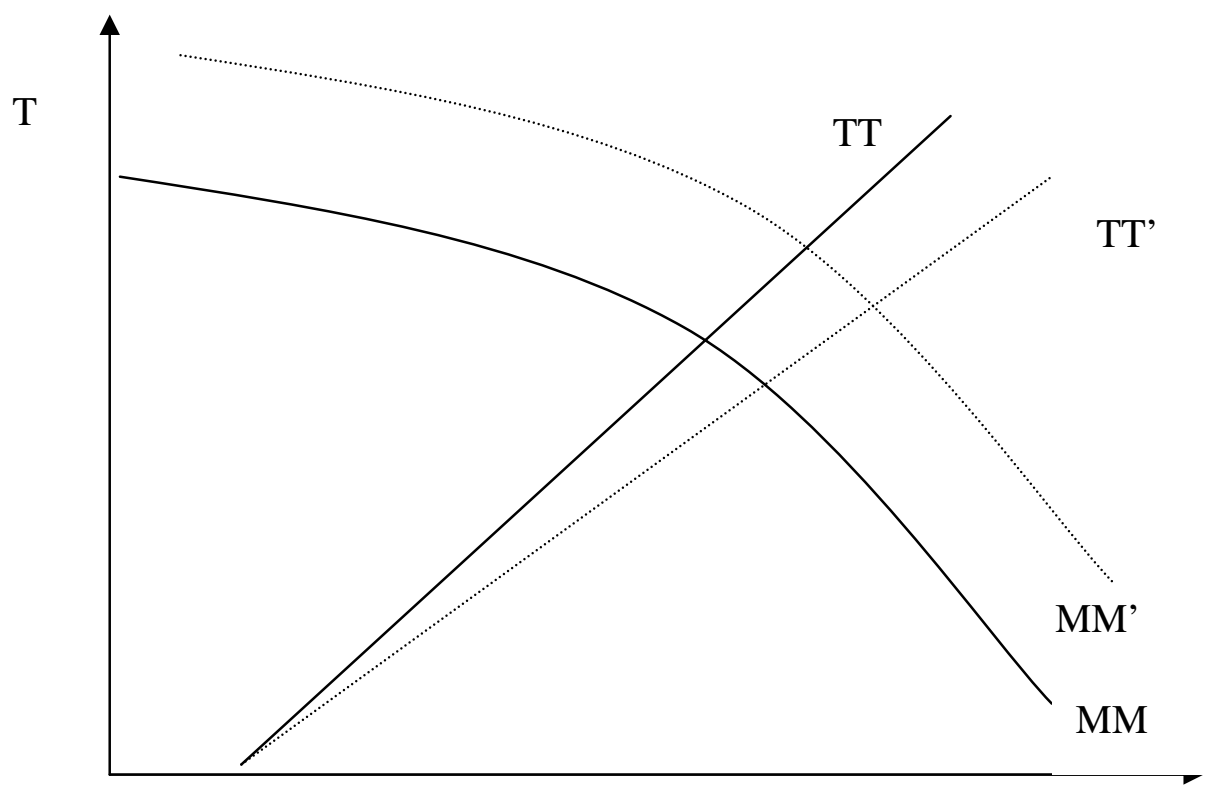

Figure 3: The effect of reducing barriers to entry

\footnotetext{
${ }^{11}$ The barycentre of the rotation is the point $(1,0)$
} 
So far, we have assumed that deregulation does not influence total factor productivity $A$. However, in models of price competition such as ours, theory tends to predict that, if firms are symmetric, deregulation increases the incentive to innovate (see Aghion et al., 2001). In addition, according to Schiantarelli (2005), the balance of empirical evidence in the US and in Europe suggests that productivity increases with deregulation. If we relax our assumption and let $A=A(\rho)$, with $\partial A / \partial \rho<0$, the overall impact of deregulation on training is more likely to be positive. However, we hasten to stress that postulating a negative relationship between regulation and total factor productivity is not necessary for the negative relationship between regulation and training to hold.

\section{The Empirical Model}

In the empirical application, we are interested in investigating whether changes in regulation affect training incidence, measured as the proportion of workers receiving training. Equations [14] and [15] generate in implicit form a map from deregulation $\rho$ to training incidence $T$, which is plotted in Figure 1 for a selected configuration of parameters. As described in detail in the data section below, our measures of regulation vary by sector, country and over time. Therefore, we collapse our data on training and additional controls at the same level of aggregation. As discussed in the previous section, for most of our sample a monotone (negative) relationship between regulatory barriers and training prevails. We can therefore estimate the following empirical counterpart of the theoretical model: ${ }^{12}$

$$
\ln \frac{T}{1-T_{i c t}}=\lambda_{0}+\lambda_{1} X_{i c t}+\lambda_{2} R_{i c t}+\varepsilon_{\text {ict }}
$$

where the vector $X$ includes a vector of controls, such as average age, education and firm size, $R$ is the measure of regulation, the subscript $i$ is for the industry, $c$ is for the country and $t$ is for time. We

\footnotetext{
12 From an empirical point of view, the logit specification has the advantage of focusing on percentage rather than percentage point changes in training. This advantage is considerable when the cross-country variation in training rates is large, as is the case in our data. Specification [17] implies that $\frac{\partial T}{\partial \rho}=(T(\rho) /[1-T(\rho)]) \lambda_{2}$. Yet, if $T$ is relatively small (or has relatively little variation) it is easy to show that the relationship between regulation and training is close to be linear. However, we consider also an alternative linear specification of the model.
} 
postulate that the error term is as follows

$$
\varepsilon_{i c t}=\xi_{i c}+\xi_{i t}+\xi_{c t}+\omega_{i c t}
$$

where $\xi_{i c}$ is a country by industry effect, $\xi_{i t}$ is an industry by time effect, $\xi_{c t}$ is a country by time effect, and $\omega_{i c t}$ is a standard disturbance. We control for these unobserved effects by including in the regression country by sector, country by year, and sector by year dummies. The country by sector dummies capture cross country differences in the structure of each industry, including differences in the parameters $\sigma, \gamma, \beta$ and $A$; the sector by year effects capture the time varying differences in trend growth between affected industries (treated group) and industries not affected directly by deregulation (control group); the country by year dummies absorb country-specific macroeconomic effects, countrywide changes in policy (notably training policy and nation-wide regulation, on which we have no data see below) as well as changes in the routing of the questionnaire and/or the exact formulation of the training question.

Our key interest lies in estimating the coefficient $\lambda_{2}$, which measures the relationship between product market regulation and training. A negative estimate of $\lambda_{2}$ would confirm that a negative relationship between regulation and training prevails. Strictly speaking, however, our theoretical model suggests that this coefficient is positive for low levels of regulation and negative for higher values. We can therefore try to capture this bell-shaped pattern by fitting a quadratic in our regulatory indicators. Yet, since we do not have data on nation-wide aspects of regulation affecting all sectors, we will have to do a number of arbitrary assumptions to estimate these quadratic specifications, and results obtained from them must be viewed as a tentative extension.

Notice that the model is expressed in terms of training stocks. However, we only have data on training flows (see next section). However, recalling that the training flow $\tau$ is equal to $T(\delta+g) /(1+g)$, where $\delta$ is the training depreciation rate and $g$ is the steady state growth rate of the training stock, we can, re-specify our empirical model in terms of the training flow $\tau$, by simply substituting it for $T$ in equation [17]. Alternatively, we can construct training stocks from training flows by following a methodology similar to Conti (2005) and Dearden et al. (2006). In particular, we assume a common depreciation rate ( $\delta=0.15$ ) and a steady state rate of growth equal to the sample average 
growth rate of training flows ${ }^{13}$, and reconstruct initial conditions under the assumption that steady state growth occurs at the beginning of the sample, which implies $\tau_{1} /(\delta+g)=T_{0}$, where $\tau_{1}$ is the training flow in the first period and $T_{0}$ the training stock in the initial period. Finally, training stocks after missing years are constructed by assuming steady state growth in those years. Insofar as these data are reconstructed, we prefer to specify our model in terms of flows and use training stock data only in a sensitivity analysis.

Specification [17] assumes that, conditional on the vector $\mathrm{X}$, only product market regulation variables can vary by country, year and sector, and that confounding factors are fully accounted for by the combination of country by year, country by sector and sector by year dummies. While this is plausible, we cannot rule out the possibility that variables measuring labour market institutions at the same level of detail as regulation variables could affect training incidence. If this is so, failure to account for these effects could erroneously attribute them to changes in product market regulation. Therefore, we also experiment with specifications that augment the vector $\mathrm{X}$ with available measures of labour market institutions.

\section{Data}

We use three main sources of data: a) an OECD database on training and other labour market variables; b) OECD regulatory indicators for seven non-manufacturing industries (electricity, gas, air transport, road transport, railways, post and telecommunications); c) sector-level information on output, imports and labour and capital inputs available in the OECD STAN database and the companion 60industry database of the Groningen Growth and Development Centre.

The OECD database on training is drawn from the EU Labour Force Surveys. It contains information on training and a number labour market variables (namely age, gender, education, parttime/full-time status, occupation, industry, firm-size, tenure, whether the contract is temporary or permanent, whether the activity is in the country of residence, participation in training, type of training and training duration) for employed workers of 23 European countries from 1992 to 2002 (with many missing values, corresponding to countries and years where questions on training were not administered or data on training are unreliable). Data have been collected in the second quarter of each

\footnotetext{
${ }^{13}$ In the steady state flows and stocks grow at the same rate. In country/sector units where a decrease of training flows is observed, the steady state growth rate is set to zero.
} 
year (March in most countries). Quantitative variables (such as tenure or firm size) are divided into categories (see the appendix for more details). As regards to age, we dispose of categories covering five-year intervals. We then reconstruct an ordinal variable by applying to all observations in each category the mean age of the category. Data are semi-aggregated insofar as organized by cells. Each cell corresponds to a combination of categories. Available cells cover all non-empty combinations with one category for each variable. Population weights are reported for each cell.

Training data refer to participation in any education or training course in the 4 weeks preceding the interview (1 week for France). Data on the type of training and its length are often missing. For this reason, we do not use this information. In order to avoid that initial and close-to-retirement education confound the information on workplace training, we limit our analysis to full-time employees with at least 1 month of tenure, aged between 25 and 54 years, and working in their country of residence. Data comparability is better within cells belonging to the same country and year, since the exact formulation of the training question as well as the routing of the questionnaire may change from one country to another and from one year to another. Descriptive statistics on training are available in the Appendix.

We collapse our data on training and selected other labour market variables (education, age, gender and firm size) at the level of sectors. Industries are available at the 2 digit level of the NACE rev.1 classification (that, at the 2 digit level, corresponds to the ISIC rev. 3, with extremely few exceptions) for most countries and years in manufacturing. In services, they are available at a slightly more disaggregated level than 1 digit of NACE rev. 1. However, since only NACE 1970 is available for 1992 and for certain country-year pairs, we are obliged to aggregate a few industries in order to construct our sector-level database. The final list of industries is available in the Appendix.

We have access to detailed OECD indicators on anti-competitive product market regulation for seven 2 or 3 digit non-manufacturing industries. Data are available on an annual basis and span from 1975 to 2003 for 21 OECD countries (Australia, Austria, Belgium, Canada, Switzerland, Germany, Denmark, Spain, Finland, France, UK, Greece, Ireland, Italy, Japan, the Netherlands, Norway, Portugal, Sweden, US, New Zealand). Following Alesina et al. (2005) we use these data to construct time-series indicators of regulatory barriers for three more aggregate industries (utilities, transport, and communication services), for which we have training data (see above). Detailed regulatory indicators concern sector-specific entry barriers, public ownership, the market share of the dominant player(s) when relevant (in the telephone, gas and railroad sectors), vertical integration in network industries and price controls when relevant (in the road freight industry). Outside the scope of these indicators are nation-wide aspects of regulations applying to all industries, such as administrative barriers to 
entrepreneurship (administrative barriers on start-ups, general features of the licensing and permit system, etc...), since these data are not available in time-series in the OECD database.

Available indicators vary between 0 and 6 from the least to the most regulated. Entry barriers cover legal limitations on the number of companies and rules on vertical integration of network industries. A value of 0 corresponds to free entry. By contrast, a value of 6 applies when entry is severely restricted. Public ownership measures the share of equity owned by central or municipal governments, and takes a value of 0 in the case of no equity and a value of 6 in the case of full ownership. All other indicators are similarly defined. More details on these indicators are available from Nicoletti et al. (2001), Alesina et al. (2005) and Conway and Nicoletti(2006).

We construct our aggregate indicators following the same methodology of Alesina et al. (2005). This involves two steps. First, separate indicators of barriers to entry, public ownership, market structure, vertical integration and price controls for each of the seven industries are averaged to obtain four coarser (and partially alternative) indicators: REGOL, the overall indicator including all the regulation dimensions; BEVI, which summarizes barriers to entry (comprising legal restrictions and vertical integration); REGPO, which summarizes the degree of public ownership; and REGNO, which includes all dimensions except public ownership. As our model applies explicitly to barriers to entry we expect BEVI to be more related to training than REGPO. The same might apply to REGNO insofar as the presence of price controls and a very concentrated market can, to a certain extent, be seen as additional barriers to start-ups. Second, the same indicators for the three more aggregated industries are obtained by simple averaging the values of the corresponding sub-industries.

Once the four indicators of regulation are matched to our training data we obtain 402 country by sector by time non-missing observations ${ }^{14}$ concerning three (typically regulated) service industries for 15 European countries and a maximum of 11 years. Yet, these industries account for a small share of total employment (about 7.5\% in 2002). Moreover, in the event that reforms in these three sectors have occurred almost simultaneously, the effect of the variation in regulation on training incidence risks to be swept away once country per year dummies are included in the empirical analysis.

To circumvent this problem, we add manufacturing industries to our dataset. For these industries, regulation concerns essentially administrative burdens, limitations to foreign direct investment as well as barriers to trade, at least in European countries. Now, only the last two barriers can be considered to be sector-specific. But for them, due to the coming into action of the Single

\footnotetext{
${ }^{14}$ This number drop further to 398 in logit specifications such as [17] since training incidence is zero for some observations.
} 
Market Programme (SMP) in 1992, it can be assumed that their time profile is flat since at least 1994 for the 12 countries that were EU members in 1992 (see e.g. Bottasso and Sembenelli, 2001). ${ }^{15}$ The same argument can be applied to Austria, Finland, Norway and Sweden from 1995 (see e.g. Baldwin et al., 1996, and Gullstrand and Johansson, 2005). ${ }^{16}$ This is equivalent to assume that - since 1994 for the majority of countries and since 1995 for a few countries - regulation in manufacturing has been equal to an arbitrary constant, which we control for with country by industry dummies. In sum, we construct an extended dataset starting from the three non-manufacturing industries by adding manufacturing and by dropping pre-SMP years. In practice, this is equivalent to using a difference in difference estimator, where manufacturing sectors are used as the control group and services are the treated group. We end up with a sample composed of 15 countries and 13 industries for a maximum of 7 years for each country-industry pair, and for a total of 1339 observations once observations with missing information on training is excluded. ${ }^{17}$

As discussed above, ideally we would like to estimate a bell-shaped relationship between regulation and training. However, strictly speaking this is impossible in our data, since we do not have a time-series for those nation-wide aspects of regulation that apply to all sectors (such as administrative barriers to start-ups). In fact these indicators exist in the OECD Database only for two years (1998 and 2003). In specifications such as [17] this component of regulation is controlled for by country by time dummies. However, this is no longer the case in specifications with a quadratic. On a tentative basis we can add the nation-wide indicator of administrative barriers to start-ups in 1998 to our sector-specific indicators of regulation, assuming the latter to be 0 in manufacturing, to obtain a reconstructed indicator of regulatory barriers that is more comparable across countries. Yet this indicator will miss the effect of administrative reforms that took place in the 1990s.

The other additional relevant co-variates are taken from the OECD STAN database and the Groningen's 60-Industry database. Notably, one might expect that the effects of deregulation are fully realised with a certain delay and/or that, particularly in certain manufacturing industries, globalisation is increasing the competitive pressure on businesses independently of regulation. To account for this

\footnotetext{
${ }^{15}$ Bottasso and Sembenelli (2001) report that, on average, 75\% of the measures implied by the SMP agreement were already transposed into national legal systems at the time when the SMP came into action, and that virtually all measures were transposed shortly after.

${ }^{16}$ According to the first editions of the Single Market Scoreboard (EC, 1997, 1998), by 1997 Finland, Norway and Sweden were among the best performing countries as far as transposition of EC directives is concerned. Only Austria appeared to lag behind, but its gap with other EU countries was closed in 1998. For this reason we check that our results are robust to exclusion of Austria prior to 1998.

${ }^{17}$ This number drop further to 1294 in logit specifications such as eq. [17] since the training incidence is zero for certain observations.
} 
possibility, we include in [17] the logarithm of import penetration. Furthermore, one can imagine that growing businesses will have a greater propensity to train than downsizing businesses, insofar as in the former the proportion of new hires in need of induction training is likely to be greater, ${ }^{18}$ while in the latter the proportion of dismissals, upon which employers will be unable to recoup the cost of training, is likely to be greater. Therefore we include the logarithm of employment growth as a further control. Finally, there are good reasons to think that training might vary over the business-cycle. For instance, according to Hall (2000), re-organisations take place during slack periods when the cost of foregoing production to re-allocate resources is smaller. The case studied by Hall concerns creation/destruction of job matches and search. However, it can well apply to internal re-organization, which usually requires long periods of adaptation, learning and training before becoming again fully efficient (see also Jovanovic, 2006). In support of such a view, Sepulveda (2002) finds that on-the-job training is countercyclical using data from the US National Longitudinal Survey of Youth. To control for sector-specific business cycles we construct log employment and log worked hours gaps by subtracting to each of these variables their filtered time-series obtained applying an Hodrick-Prescott filter with standard parameters. $^{19}$

When the impact of nation-wide institutions is homogeneous across sectors, this effect is controlled in equation [17] by country per year dummies. However, certain labour market institutions might not have the same impact on training in all sectors. More specifically, Haltiwanger et al. (2006) and Micco and Pages (2006), convincingly suggest that the impact of lay-off regulations on job turnover varies according to the natural propensity of industries to adjust their labour input. They show that almost all the variation in the cross-country/cross-sector distribution of job turnover can be explained by the distribution of job turnover in the United States (that is the OECD country with the least regulated labour market) and country dummies, and that the remaining variation can be explained by an interaction between a country-specific indicator of regulatory stringency and US job turnover rates by sector. Bassanini and Venn (2007) use the same methodology to explore the impact of lay-off regulations on productivity growth. We use various US job turnover indicators by sector from Haltiwanger et al. (2006) and interact them with the OECD aggregate measure of employment

\footnotetext{
${ }^{18}$ Yet, given that training is likely to occur in the very few weeks after hiring and we exclude workers with less than one month of tenure, we probably already control for part of this effect.

${ }^{19}$ We exploit here the advantage of having reliable information on employment and hours. In fact, one can expect the countercyclical pattern of training to be more important when labour hoarding dominates employment adjustments, particularly during slowdowns. However, we check that our results are robust to substituting a more classical output gap for employment and hours gaps. In a sensitivity analysis, we also consider the investment rate as well as the level and growth of productivity to control for possible endogeneity of regulation with respect to productivity (see e.g. Duso and Röller, 2003).
} 
protection legislation (EPL), so as to obtain an indicator of EPL impact that varies by country, sector and time. Union power might also vary along these three dimensions. In order to capture this effect we use data on union density from Ebbinghaus and Visser (2000) and data on total days lost for strikes and industrial actions from the ILO LABORSTA Database that we divide by the number of employed workers using data from the Groningen's 60-Industry database. However, these data are available only for macro-sectors. Therefore we cannot do anything better than attributing their macro-sector averages to each sub-sectors.

Exact variable definitions, sources and sample statistics for the sub-sample of nonmanufacturing and the post-SMP sample of non-manufacturing and manufacturing are provided in the Appendix. Since the exact month of each regulatory reform is not known and might well be subsequent to the second quarter of the corresponding year, each regulatory indicator is lagged one year. The same applies to all other indicators, which do not come from the ELFS, insofar as they generally refer to yearly averages.

\section{Empirical results}

We start our analysis by examining the association between regulation and training incidence at the sector level. We estimate equation [17] by OLS, with the dependent variable expressed in terms of training flows. Table 1 shows, in three different panels, our results for each regulation measure when only (bi-dimensional) fixed effects are included. In the first panel, different measures of regulation are included one at a time. In the second and third panel, the barriers to entry indicators REGNO and BEVI and the public ownership indicator REGPO are included together. In each panel, Column 1 refers to transport, communications and energy only, and Column 2 extends the sample to cover manufacturing but drops pre-SMP years. The last two columns replicate results by omitting the few observations with very low training rates, for which our dependent variable assumes very large negative values.

On the one hand, the association between regulation and training is not statistically significant when we consider only public ownership (REGPO). This is also reflected in the association of the overall index (REGOL) and training, which becomes insignificant once low-training observations are excluded. On the other hand, both REGNO - the most comprehensive measure which excludes public ownership - and BEVI, which considers only strictly defined barriers to entry and vertical integration, attract a statistically significant coefficient and are negatively correlated with training incidence.

Conditional on either BEVI or REGNO, the public ownership indicator REGPO does never 
attract a statistically significant coefficient. Therefore, in the ensuing discussion we shall focus on the indicator of barriers to entry and vertical integration (BEVI). We will also drop low-training observations. $^{20}$ Table 2 presents the results obtained by adding to the specifications in Table 1 additional controls: the mean age of employees in the industry, the share of women in the industry, the shares of employees with upper secondary education or less in the industry, the employment share of firms with less than 10 employees in the industry, the logarithm of import penetration (which is defined only for manufacturing industries), employment and hours gaps and employment growth. ${ }^{21}$ Panel A presents the results for the service plus energy sample, and Panel B for the extended non-SMP sample, which includes manufacturing.

Table 1. Estimates of logit specifications of training as a function of product market regulation. Dependent variable: inverse logistic transformation of training participation rates.

Panel A: One regulatory variable per model, OLS

\begin{tabular}{|c|c|c|c|c|}
\hline & $(1)$ & $(2)$ & (3) & $(4)$ \\
\hline & $\begin{array}{c}\text { Services + } \\
\text { Energy only }\end{array}$ & $\begin{array}{c}\text { Services, } \\
\text { Energy and } \\
\text { Manufacturing }\end{array}$ & $\begin{array}{c}\text { Services + } \\
\text { Energy only } \\
\text { (no outliers) }\end{array}$ & $\begin{array}{c}\text { Services, } \\
\text { Energy and } \\
\text { Manufacturing } \\
\text { (no outliers) }\end{array}$ \\
\hline Overall index (REGOL) & $\begin{array}{c}-0.145 \\
{[0.061]^{* *}}\end{array}$ & $\begin{array}{c}-0.112 \\
{[0.065]^{*}}\end{array}$ & $\begin{array}{c}-0.141 \\
{[0.061]^{* *}}\end{array}$ & $\begin{array}{c}-0.096 \\
{[0.065]}\end{array}$ \\
\hline Excluding public ownership (REGNO) & $\begin{array}{c}-0.122 \\
{[0.047]^{* *}}\end{array}$ & $\begin{array}{c}-0.102 \\
{[0.045]^{* *}}\end{array}$ & $\begin{array}{c}-0.142 \\
{[0.046]^{* * *}}\end{array}$ & $\begin{array}{c}-0.098 \\
{[0.045]^{* *}}\end{array}$ \\
\hline Barriers to entry only (BEVI) & $\begin{array}{c}-0.096 \\
{[0.037]^{* *}}\end{array}$ & $\begin{array}{c}-0.089 \\
{[0.036]^{* *}}\end{array}$ & $\begin{array}{c}-0.123 \\
{[0.035]^{* * *}}\end{array}$ & $\begin{array}{c}-0.092 \\
{[0.035]^{* * *}}\end{array}$ \\
\hline Public ownership only (REGPO) & $\begin{array}{c}-0.003 \\
{[0.046]}\end{array}$ & $\begin{array}{c}0.002 \\
{[0.060]}\end{array}$ & $\begin{array}{c}0.026 \\
{[0.045]}\end{array}$ & $\begin{array}{c}0.022 \\
{[0.058]}\end{array}$ \\
\hline Country by sector dummies & yes & yes & yes & Yes \\
\hline Country by year dummies & yes & yes & yes & Yes \\
\hline Sector by year dummies & yes & yes & yes & Yes \\
\hline Number of observations & 398 & 1294 & 388 & 1261 \\
\hline
\end{tabular}

\footnotetext{
${ }^{20}$ Results are quite similar if we use REGNO and/or we keep low-training observations.

${ }^{21}$ We also considered various specifications including the investment rate as well as the level and growth of productivity. Yet, these controls never turn out as statistically significant and their inclusion does not change the sensitivity of training to regulation (results available from authors upon request).
} 
Panel B: Separating out public ownership, OLS

\begin{tabular}{|c|c|c|c|c|}
\hline & $(1)$ & $(2)$ & (3) & (4) \\
\hline & $\begin{array}{c}\text { Services }+ \\
\text { Energy only }\end{array}$ & $\begin{array}{c}\text { Services, } \\
\text { Energy and } \\
\text { Manufacturing }\end{array}$ & $\begin{array}{c}\text { Services + } \\
\text { Energy only } \\
\text { (no outliers) }\end{array}$ & $\begin{array}{c}\text { Services, } \\
\text { Energy and } \\
\text { Manufacturing } \\
\text { (no outliers) }\end{array}$ \\
\hline Excluding public ownership (REGNO) & $\begin{array}{c}-0.126 \\
{[0.051]^{* *}}\end{array}$ & $\begin{array}{c}-0.103 \\
{[0.046]^{* *}}\end{array}$ & $\begin{array}{c}-0.155 \\
{[0.049]^{* * *}}\end{array}$ & $\begin{array}{c}-0.102 \\
{[0.046]^{* *}}\end{array}$ \\
\hline Public ownership only (REGPO) & $\begin{array}{c}0.019 \\
{[0.049]}\end{array}$ & $\begin{array}{c}0.014 \\
{[0.059]} \\
\end{array}$ & $\begin{array}{c}0.055 \\
{[0.046]}\end{array}$ & $\begin{array}{c}0.033 \\
{[0.057]} \\
\end{array}$ \\
\hline Country by sector dummies & yes & yes & yes & Yes \\
\hline Country by year dummies & yes & yes & yes & Yes \\
\hline Sector by year dummies & yes & yes & yes & Yes \\
\hline Number of observations & 398 & 1294 & 388 & 1261 \\
\hline R-squared & 0.96 & 0.93 & 0.96 & 0.93 \\
\hline
\end{tabular}

Panel C: Barriers to entry and public ownership, OLS

\begin{tabular}{|c|c|c|c|c|}
\hline & $(1)$ & $(2)$ & (3) & $(4)$ \\
\hline & $\begin{array}{c}\text { Services }+ \\
\text { Energy only }\end{array}$ & $\begin{array}{c}\text { Services, } \\
\text { Energy and } \\
\text { Manufacturing }\end{array}$ & $\begin{array}{l}\text { Services + } \\
\text { Energy only } \\
\text { (no outliers) }\end{array}$ & $\begin{array}{c}\text { Services, } \\
\text { Energy and } \\
\text { Manufacturing } \\
\text { (no outliers) }\end{array}$ \\
\hline Barriers to entry only (BEVI) & $\begin{array}{c}-0.099 \\
{[0.041]^{* *}}\end{array}$ & $\begin{array}{c}-0.089 \\
{[0.036]^{* *}}\end{array}$ & $\begin{array}{c}-0.133 \\
{[0.038]^{* * *}}\end{array}$ & $\begin{array}{c}-0.093 \\
{[0.035]^{* * *}}\end{array}$ \\
\hline Public ownership only (REGPO) & $\begin{array}{c}0.017 \\
{[0.049]}\end{array}$ & $\begin{array}{c}0.01 \\
{[0.058]}\end{array}$ & $\begin{array}{c}0.057 \\
{[0.045]}\end{array}$ & $\begin{array}{c}0.031 \\
{[0.056]}\end{array}$ \\
\hline Country by sector dummies & yes & yes & yes & Yes \\
\hline Country by year dummies & yes & yes & yes & Yes \\
\hline Sector by year dummies & yes & yes & yes & Yes \\
\hline Number of observations & 398 & 1294 & 388 & 1261 \\
\hline R-squared & 0.96 & 0.93 & 0.96 & 0.93 \\
\hline
\end{tabular}

Note: robust standard errors within brackets. All regressions include country by year, sector by year and country by sector dummies. In Panel A each cell refers to a different specification. In Panel B each column refers to a different specification. Observations with training participation rate smaller than $0.5 \%$ are excluded in Columns 3 and 4 . **, ***: significant at the $5 \%$ and $1 \%$ level, respectively.

It turns out that training incidence is significantly lower when the share of low educated individuals - with ISCED less than 3 - is higher, a standard result in the training literature (see Bassanini et al, 2007). Consistently with the finding of Sepulveda (2002) we also find that training incidence is countercyclical. However, the negative relationship is not statistically significant in the case of the employment gap. Employment growth appears to be negatively associated to training in the services plus energy sample. Yet, this relationship has the wrong sign (theory would rather predict a positive relationship) and becomes insignificant in the post-SMP sample with all industries. Finally, the logarithm of import penetration is positively related to training in a (weakly) significant way, yielding some support to the idea that, for the tradeable sector, globalisation can have an additional effect on 
training independently of deregulation.

Table 2. Estimates of logit specifications of training as a function of product market regulation and additional controls. Dependent variable: inverse logistic transformation of training participation rates. Panel A: Services + Energy only, OLS

\begin{tabular}{|c|c|c|c|c|}
\hline & $(1)$ & $(2)$ & (3) & (4) \\
\hline & All controls & $\begin{array}{c}\text { All significant } \\
\text { controls }\end{array}$ & $\begin{array}{l}\text { Significant } \\
\text { controls, no } \\
\text { employment } \\
\text { growth }\end{array}$ & $\begin{array}{l}\text { (3) plus } \\
\text { employment } \\
\text { gap }\end{array}$ \\
\hline Barriers to entry only (BEVI) & $\begin{array}{c}-0.123 \\
{[0.040]^{* * *}}\end{array}$ & $\begin{array}{c}-0.119 \\
{[0.039]^{* * *}}\end{array}$ & $\begin{array}{c}-0.129 \\
{[0.039]^{* * *}}\end{array}$ & $\begin{array}{c}-0.124 \\
{[0.039]^{* * *}}\end{array}$ \\
\hline Share males & $\begin{array}{c}0.002 \\
{[0.804]}\end{array}$ & & & \\
\hline Average age & $\begin{array}{c}0.019 \\
{[0.039]}\end{array}$ & & & \\
\hline Share firms with $>50$ employees & $\begin{array}{c}0.067 \\
{[0.524]}\end{array}$ & & & \\
\hline Share low education & $\begin{array}{c}-1.897 \\
{[0.851]^{* *}}\end{array}$ & $\begin{array}{c}-1.371 \\
{[0.560]^{* *}}\end{array}$ & $\begin{array}{c}-1.453 \\
{[0.563]^{* *}}\end{array}$ & $\begin{array}{c}-1.529 \\
{[0.573]^{* * *}}\end{array}$ \\
\hline Share medium education & $\begin{array}{c}-0.554 \\
{[0.718]}\end{array}$ & & & \\
\hline Hours gap & $\begin{array}{c}-6.723 \\
{[3.023]^{* *}}\end{array}$ & $\begin{array}{c}-5.433 \\
{[2.838]^{*}}\end{array}$ & $\begin{array}{c}-5.704 \\
{[2.893]^{*}}\end{array}$ & $\begin{array}{c}-5.965 \\
{[2.894]^{* *}}\end{array}$ \\
\hline Employment gap & $\begin{array}{c}0.395 \\
{[0.698]}\end{array}$ & & & $\begin{array}{l}-0.587 \\
{[0.550]}\end{array}$ \\
\hline Employment growth & $\begin{array}{c}-1.612 \\
{[0.645]^{* *}}\end{array}$ & $\begin{array}{c}-1.407 \\
{[0.517]^{* * *}}\end{array}$ & & \\
\hline Country by sector dummies & yes & yes & yes & Yes \\
\hline Country by year dummies & yes & yes & yes & Yes \\
\hline Sector by year dummies & yes & yes & yes & Yes \\
\hline Number of observations & 364 & 373 & 373 & 373 \\
\hline R-squared & 0.96 & 0.96 & 0.96 & 0.96 \\
\hline
\end{tabular}


Table 2. (continued).

Panel B: Services, Energy and Manufacturing, post-SMP, OLS

\begin{tabular}{|c|c|c|c|c|}
\hline & $(1)$ & $(2)$ & (3) & $(4)$ \\
\hline & All controls & $\begin{array}{l}\text { All significant } \\
\text { controls plus } \\
\text { employment } \\
\text { growth }\end{array}$ & $\begin{array}{c}\text { Significant } \\
\text { controls only }\end{array}$ & $\begin{array}{l}\text { (3) plus } \\
\text { employment } \\
\text { gap }\end{array}$ \\
\hline Barriers to entry only (BEVI) & $\begin{array}{c}-0.096 \\
{[0.037]^{* * *}}\end{array}$ & $\begin{array}{c}-0.092 \\
{[0.035]^{* * *}}\end{array}$ & $\begin{array}{c}-0.094 \\
{[0.035]^{* * *}}\end{array}$ & $\begin{array}{c}-0.093 \\
{[0.036]^{* * *}}\end{array}$ \\
\hline Share males & $\begin{array}{c}0.034 \\
{[0.436]}\end{array}$ & & & \\
\hline Average age & $\begin{array}{c}0.012 \\
{[0.027]}\end{array}$ & & & \\
\hline Share firms with $>50$ employees & $\begin{array}{c}0.080 \\
{[0.316]}\end{array}$ & & & \\
\hline Share low education & $\begin{array}{c}-1.867 \\
{[0.564]^{* * *}}\end{array}$ & $\begin{array}{c}-1.460 \\
{[0.443]^{* * *}}\end{array}$ & $\begin{array}{c}-1.462 \\
{[0.443]^{* * *}}\end{array}$ & $\begin{array}{c}-1.467 \\
{[0.445]^{* * *}}\end{array}$ \\
\hline Share medium education & $\begin{array}{c}-0.544 \\
{[0.426]}\end{array}$ & & & \\
\hline Log import penetration & $\begin{array}{c}0.404 \\
{[0.191]^{* *}}\end{array}$ & $\begin{array}{c}0.312 \\
{[0.176]^{*}}\end{array}$ & $\begin{array}{c}0.319 \\
{[0.178]^{*}}\end{array}$ & $\begin{array}{c}0.314 \\
{[0.174]^{*}}\end{array}$ \\
\hline Hours gap & $\begin{array}{c}-3.048 \\
{[1.225]^{* *}}\end{array}$ & $\begin{array}{c}-2.721 \\
{[1.158]^{* *}}\end{array}$ & $\begin{array}{c}-2.741 \\
{[1.162]^{* *}}\end{array}$ & $\begin{array}{c}-2.770 \\
{[1.175]^{* *}}\end{array}$ \\
\hline Employment gap & $\begin{array}{c}-0.043 \\
{[0.684]}\end{array}$ & & & $\begin{array}{c}-0.097 \\
{[0.529]}\end{array}$ \\
\hline Employment growth & $\begin{array}{c}-0.444 \\
{[0.464]}\end{array}$ & $\begin{array}{c}-0.282 \\
{[0.386]}\end{array}$ & & \\
\hline Country by sector dummies & Yes & yes & Yes & Yes \\
\hline Country by year dummies & Yes & yes & Yes & Yes \\
\hline Sector by year dummies & Yes & yes & Yes & Yes \\
\hline Number of observations & 1196 & 1235 & 1235 & 1235 \\
\hline R-squared & 0.93 & 0.93 & 0.93 & 0.93 \\
\hline
\end{tabular}

Note: robust standard errors within brackets. Observations with training participation rates smaller than $0.5 \%$ are excluded. *, **, ***: significant at the $10 \%, 5 \%$ and $1 \%$ level, respectively.

We can check the quality of our preferred specification (Column 3 of Panel B in Table 2) by looking at how well it predicts changes in training without considering the contribution of bidimensional dummies. In order to do so, in Table 3 we predict, for each sector, the average variation between the earliest and latest dates in the post-SMP sample (1995 and 2002, respectively) excluding countries where information is totally or partially missing in one of these years. In three sectors (other manufacturing and recycling; land and air transport; machinery, excluding computers and precision instruments) the change in the ratio between the proportion of workers that received training and the proportion of those that did not is over-predicted by more than 20 percentage points. In two other sectors (rubber and plastics and other non-metallic mineral products; metals and fabricated metal products), the model under-predicts the change of that ratio by a comparable amount. Finally, in the remaining 8 industries prediction errors are acceptably small. 
Table 3. Actual vs. predicted change in training (inverse logistic transformation).

\begin{tabular}{c|ccccc}
\hline & $(1)$ & $(2)$ & $(3)$ & $(4)$ & $(5)$ \\
\hline Sector & $\begin{array}{c}\Delta \text { log } \\
\text { (training / } \\
(1-\text {-training) }\end{array}$ & $\begin{array}{c}\text { Predicted by } \Delta \\
\text { Barriers to } \\
\text { entry (BEVI) }\end{array}$ & $\begin{array}{c}(2)+\text { predicted } \\
\text { by } \Delta \text { log import } \\
\text { penetration }\end{array}$ & $\begin{array}{c}\text { (3) + predicted } \\
\text { by } \Delta \text { other } \\
\text { controls }\end{array}$ & $\begin{array}{c}\text { Predicted - } \\
\text { Actual } \\
((4)-(1))\end{array}$ \\
\hline $36-37$ & -0.192 & 0 & 0.131 & 0.286 & 0.478 \\
$60+62$ & -0.262 & 0.097 & 0.097 & 0.165 & 0.427 \\
$29+31+32$ & 0.048 & 0 & 0.097 & 0.250 & 0.202 \\
$30+33$ & 0.049 & 0 & 0.090 & 0.189 & 0.139 \\
$17-19$ & 0.078 & 0 & 0.175 & 0.217 & 0.139 \\
64 & 0.394 & 0.308 & 0.308 & 0.466 & 0.071 \\
$40-41$ & 0.249 & 0.238 & 0.238 & 0.296 & 0.047 \\
$34-35$ & 0.162 & 0 & 0.147 & 0.207 & 0.045 \\
$23-24$ & 0.218 & 0 & 0.083 & 0.227 & 0.009 \\
$20-22$ & 0.217 & 0 & 0.029 & 0.171 & -0.047 \\
$15-16$ & 0.363 & 0 & 0.058 & 0.234 & -0.129 \\
$25-26$ & 0.416 & 0 & 0.079 & 0.206 & -0.211 \\
$27-28$ & 0.428 & 0 & 0.058 & 0.179 & -0.249 \\
\hline Average & 0.171 & 0.052 & 0.123 & 0.239 & 0.068 \\
\hline
\end{tabular}

Note: Sectors are ranked according to the difference between predicted and actual values. Countries with missing observations in 1995 or 2002 are excluded from this computation. Changes are computed on the basis of Column 3 in Panel B of Table 2, without considering the contribution of bi-dimensional dummies.

While actual training rates increased on average by about 17 percent between 1995 and 2002, our model predicts a close to 24 percent increase. ${ }^{22}$ Overall, important prediction errors occur in certain manufacturing industries and in the transport industry. This is re-assuring insofar as we have no direct indicators of regulation in manufacturing and our indicator for the transport industry suffers from aggregation errors: this industry is in fact dominated in employment terms by the road freight subindustry, in which almost no variation in barriers to entry occurred within the period, while most of the regulatory variation is due to the air transport industry. Unfortunately, our data do not permit further disaggregation of this industry. Yet, dropping it from the sample does not change the results.

As discussed above, we can try to capture a bell-shaped relationship between regulation and training by formulating a specification including a quadratic term, where regulation is redefined by adding the 1998 indicator of nation-wide administrative barriers to start-ups to our sector-specific indicators of regulation. However, no significant evidence of a bell-shaped relationship emerges (Table 4). This result might be due to the fact that our indicators are poorly comparable in levels across countries and over time (see data section above). Alternatively, this result can be viewed as consistent with the fact that, for most of our sample, our theoretical model predicts a negative relationship.

\footnotetext{
${ }^{22}$ Note that with small values of the dependent variable (the sample average is about 8 percent) percentage changes of the ratio of proportions and percentage changes of the absolute value almost coincide, that is $\Delta \log (\tau /[1-\tau]) \cong \Delta \log \tau$.
} 
Table 4. Estimates of logit specifications of training as a function of product market regulation and its square.

Dependent variable: inverse logistic transformation of training participation rates.

\begin{tabular}{|c|c|c|c|c|}
\hline & $(1)$ & $(2)$ & $(3)$ & $(4)$ \\
\hline & $\begin{array}{c}\text { Services + } \\
\text { energy only }\end{array}$ & $\begin{array}{c}\text { Services, } \\
\text { Energy and } \\
\text { Manufacturing }\end{array}$ & $\begin{array}{c}\text { Services + } \\
\text { energy only } \\
\text { (baseline } \\
\text { controls) }\end{array}$ & $\begin{array}{c}\text { Services, } \\
\text { Energy and } \\
\text { Manufacturing } \\
\text { (baseline } \\
\text { controls) }\end{array}$ \\
\hline Barriers to entry only (BEVI) & $\begin{array}{c}-0.133 \\
{[0.166]}\end{array}$ & $\begin{array}{c}-0.233 \\
{[0.113]^{* *}}\end{array}$ & $\begin{array}{c}-0.147 \\
{[0.172]}\end{array}$ & $\begin{array}{c}-0.23 \\
{[0.116]^{* *}}\end{array}$ \\
\hline BEVI squared / 100 & $\begin{array}{c}-0.058 \\
{[0.991]}\end{array}$ & $\begin{array}{c}0.887 \\
{[0.683]}\end{array}$ & $\begin{array}{c}-0.054 \\
{[0.975]}\end{array}$ & $\begin{array}{c}0.818 \\
{[0.684]}\end{array}$ \\
\hline Share Low Education & & & $\begin{array}{c}-1.501 \\
{[0.561]^{* * *}}\end{array}$ & $\begin{array}{c}-1.476 \\
{[0.445]^{* * *}}\end{array}$ \\
\hline Log import penetration & & & & $\begin{array}{c}0.196 \\
{[0.181]}\end{array}$ \\
\hline Log import penetration squared / 100 & & & & $\begin{array}{c}6.649 \\
{[7.517]}\end{array}$ \\
\hline Hours gap & & & $\begin{array}{c}-5.499 \\
{[3.019]^{*}}\end{array}$ & $\begin{array}{c}-2.535 \\
{[1.167]^{* *}}\end{array}$ \\
\hline Country by sector dummies & Yes & yes & Yes & Yes \\
\hline Country by year dummies & Yes & yes & Yes & Yes \\
\hline Sector by year dummies & Yes & yes & Yes & Yes \\
\hline Number of observations & 388 & 1261 & 373 & 1235 \\
\hline R-squared & 0.96 & 0.93 & 0.96 & 0.93 \\
\hline
\end{tabular}

Note: Each specification is estimated with OLS. Robust standard errors within brackets. Observations with training participation rates smaller than $0.5 \%$ are excluded. *, **, ***: significant at the $10 \%, 5 \%$ and $1 \%$ level, respectively.

Since there are only 15 countries in our sample, we ask whether our results are driven by one specific country. For our preferred specification, Figure 2 plots the estimates of the parameter of interest, which captures the impact of BEVI on training, obtained by excluding one country at a time. Estimates appear to be relatively stable and always significant at the $10 \%$ level. $^{23}$

\footnotetext{
${ }^{23}$ Upon exclusion of Denmark, the impact of BEVI is significant only at the $10 \%$ level. However, if we further exclude any of the countries that are outliers in the other direction (such as Belgium, Austria or Greece) together with Denmark, estimates of our key parameter become again significant at the $5 \%$ level.
} 
Figure 4. Sensitivity to country coverage

10\% confidence interval: upper bound _ estimated coefficient - - - - 10\% confidence interval: lower bound

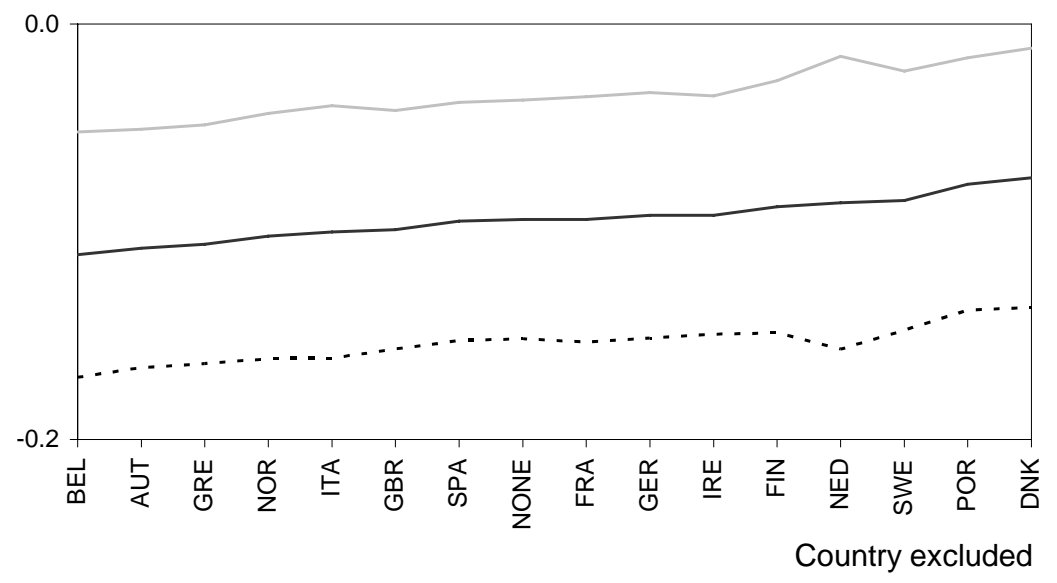

Note: The figure shows central estimates and confidence intervals obtained by re-estimating the model of Column 3 in Panel B of Table 2 excluding one country at a time. NONE identifies the specification with all 15 countries for the purpose of comparison.

Next, we check the robustness of our findings to changes in the dependent variable, and report our results in the four rows of Table 5 below. First, we use estimated training stocks instead of training flows as the dependent variable (and estimate the impact of regulation on training by using logit, linear and log-linear specifications, after excluding observations for which training flows are missing). ${ }^{24}$ Second we use training participation rates in levels. The key parameter is always significantly negative, although only at the $10 \%$ level in two specifications.

\footnotetext{
${ }^{24}$ As the average level of the stock is about 50 percent (see Appendix), logit, log-linear and linear specifications can potentially yield quite different results.
} 
Table 5. Robustness to changes in the dependent variable.

\begin{tabular}{l|cc}
\hline & $(1)$ & $(2)$ \\
\hline Dependent variable & $\begin{array}{c}\text { Services + Energy } \\
\text { only }\end{array}$ & $\begin{array}{c}\text { Services, Energy } \\
\text { and Manufacturing }\end{array}$ \\
\hline Inverse logistic transformation of the training stock & -0.069 & -0.060 \\
& {$[0.023]^{* * *}$} & {$[0.023]^{* * *}$} \\
Level of the training stock & -0.021 & -0.027 \\
Log training stock & {$[0.010]^{* *}$} & {$[0.010]^{* * *}$} \\
Level of the training participation rate & {$[0.018]^{* * *}$} & -0.033 \\
\end{tabular}

Note: Each cell refers to a different specification estimated with OLS. Only the coefficients associated to barriers to entry (BEVI) are reported. Robust standard errors within brackets. Each specification includes also the share of loweducated, log import penetration (when applicable), hours gap and country by sector, country by time and sector by time dummies. *, **, ***: significant at the $10 \%, 5 \%$ and $1 \%$ level, respectively.

Since sector - specific labour market institutions might affect training even after controlling for bi-dimensional fixed effects, failure to account for these institutions can lead us to erroneously attribute their effects to product market deregulation.. This is particularly the case of union power, which can vary from one sector to another, and of employment protection legislation (EPL), which is known to be correlated with product market regulation across countries (see e.g. Nicoletti et al., 2001). To capture union power we augment our baseline specification with union density and the logarithm of 1 plus the number of days lost for strikes and industrial actions, ${ }^{25}$ both at the industry level. We also posit that the impact of EPL is greater in industries where firms adjust employment more frequently by using hirings and lay-offs rather than internal adjustments. We therefore interact the OECD indicator of EPL stringency (which varies by country and time) with several country-time invariant sector-specific measures of job turnover, based on US patterns of job creation and destruction. In particular we consider the total turnover rate (TURN) - defined as the sum of the job creation and job destruction rates, the excess turnover rate (EXC) - defined as the difference between the turnover rate and the absolute value of the difference between job creation and job destruction rates, and the downsizing rate (DOWN) - defined as the difference between job creation and job destruction rates. These measures are standard in the literature on job creation and destruction (see Davis et al., 1996). Excess turnover is probably a better measure for our purposes than total turnover, insofar as the latter can have similar values for sectors where hirings and quits are high and sectors where downsizing is prevalent. Results of these exercises are presented in Table $6 .^{26}$

\footnotetext{
${ }^{25}$ We use this measure rather than simply the logarithm to cope with a large number of observations with 0 days lost.

${ }^{26}$ We also experimented with interactions of turnover rates and other policies, such as gross replacement rates, but they never turn out significant and do not affect the estimate of our key parameter.
} 
Table 6. Estimates of logit specifications of training as a function of product market regulation and labour market institutions.

Dependent variable: inverse logistic transformation of training participation rates.

Panel A: Services + Energy only, OLS

\begin{tabular}{|c|c|c|c|c|}
\hline & $(1)$ & $(2)$ & (3) & $(4)$ \\
\hline & $\begin{array}{c}\text { Baseline }+ \\
\text { Union density } \\
+ \text { EPL*TURN }\end{array}$ & $\begin{array}{c}\text { Baseline + } \\
\text { Union density } \\
+ \text { EPL*EXC }\end{array}$ & $\begin{array}{l}(2)+\log \text { day } \\
\text { lost for strikes }\end{array}$ & $\begin{array}{c}(2)+ \\
\text { EPL }^{*} \text { DOWN }\end{array}$ \\
\hline Barriers to entry only (BEVI) & $\begin{array}{c}-0.129 \\
{[0.046]^{* * *}}\end{array}$ & $\begin{array}{c}-0.131 \\
{[0.047]^{* * *}}\end{array}$ & $\begin{array}{c}-0.147 \\
{[0.051]^{* * *}}\end{array}$ & $\begin{array}{c}-0.137 \\
{[0.046]^{* * *}}\end{array}$ \\
\hline Share low education & $\begin{array}{c}-1.387 \\
{[0.754]^{*}}\end{array}$ & $\begin{array}{c}-1.39 \\
{[0.753]^{*}}\end{array}$ & $\begin{array}{c}-0.893 \\
{[0.970]}\end{array}$ & $\begin{array}{c}-1.613 \\
{[0.740]^{* *}}\end{array}$ \\
\hline Hours gap & $\begin{array}{c}-3.556 \\
{[2.955]}\end{array}$ & $\begin{array}{c}-3.64 \\
{[2.932]}\end{array}$ & $\begin{array}{c}-4.647 \\
{[2.958]}\end{array}$ & $\begin{array}{c}-3.674 \\
{[2.899]}\end{array}$ \\
\hline Union density & $\begin{array}{c}-0.036 \\
{[0.015]^{* *}}\end{array}$ & $\begin{array}{c}-0.032 \\
{[0.015]^{* *}}\end{array}$ & $\begin{array}{c}-0.034 \\
{[0.019]^{*}}\end{array}$ & $\begin{array}{c}-0.04 \\
{[0.016]^{* *}}\end{array}$ \\
\hline EPL*TURN & $\begin{array}{c}-0.363 \\
{[1.614]}\end{array}$ & & & \\
\hline EPL*EXC & & $\begin{array}{c}-1.259 \\
{[1.503]}\end{array}$ & $\begin{array}{c}-1.057 \\
{[1.575]}\end{array}$ & $\begin{array}{c}-3.883 \\
{[1.885]^{* *}}\end{array}$ \\
\hline Log (day lost per worker) & & & $\begin{array}{c}-0.123 \\
{[0.547]}\end{array}$ & \\
\hline EPL*DOWN & & & & $\begin{array}{c}-8.606 \\
{[4.688]^{*}}\end{array}$ \\
\hline Country by sector dummies & yes & yes & yes & Yes \\
\hline Country by year dummies & yes & yes & yes & Yes \\
\hline Sector by year dummies & yes & yes & yes & Yes \\
\hline Number of observations & 324 & 324 & 278 & 324 \\
\hline R-squared & 0.97 & 0.97 & 0.97 & 0.97 \\
\hline
\end{tabular}

Union density is negatively correlated with training in non-manufacturing industries but not in the larger post-SMP sample. On the other hand, the effect of days lost for strikes never turns out as statistically significant. The interaction between EPL and TURN is not significant. Nevertheless, and consistent with our priors, the interaction between EPL and EXC is significant in the post-SMP sample covering all industries as well as in the non-manufacturing sample if the interaction between EPL and DOWN is also added. Overall, these results are consistent with the view that EPL reduce training in industries where it is more binding, that is downsizing industries and industries that frequently reallocate resources via external adjustments. Importantly, the negative relationship between barriers to entry and training is, if any, reinforced by the inclusion of labour market institutions, suggesting that it genuinely reflects the impact of deregulation. 
Table 6. (continued).

Panel B: Services, Energy and Manufacturing, post-SMP, OLS

\begin{tabular}{|c|c|c|c|c|}
\hline & $(1)$ & $(2)$ & (3) & $(4)$ \\
\hline & $\begin{array}{c}\text { Baseline + } \\
\text { Union density } \\
+ \text { EPL*TURN }\end{array}$ & $\begin{array}{c}\text { Baseline + } \\
\text { Union density } \\
+ \text { EPL } * \text { EXC }\end{array}$ & $\begin{array}{l}\text { (2) + log day } \\
\text { lost for strikes }\end{array}$ & $\begin{array}{c}(2)+ \\
\text { EPL }^{*} \text { DOWN }\end{array}$ \\
\hline Barriers to entry only (BEVI) & $\begin{array}{c}-0.096 \\
{[0.035]^{* * *}}\end{array}$ & $\begin{array}{c}-0.099 \\
{[0.035]^{* * *}}\end{array}$ & $\begin{array}{c}-0.120 \\
{[0.036]^{* * *}}\end{array}$ & $\begin{array}{c}-0.099 \\
{[0.035]^{* * *}}\end{array}$ \\
\hline Share low education & $\begin{array}{c}-1.462 \\
{[0.444]^{* * *}}\end{array}$ & $\begin{array}{c}-1.485 \\
{[0.441]^{* * *}}\end{array}$ & $\begin{array}{c}-1.400 \\
{[0.507]^{* * *}}\end{array}$ & $\begin{array}{c}-1.481 \\
{[0.440]^{* * *}}\end{array}$ \\
\hline Log import penetration & $\begin{array}{c}0.32 \\
{[0.178]^{*}}\end{array}$ & $\begin{array}{c}0.32 \\
{[0.178]^{*}}\end{array}$ & $\begin{array}{c}0.302 \\
{[0.194]}\end{array}$ & $\begin{array}{c}0.32 \\
{[0.178]^{*}}\end{array}$ \\
\hline Hours gap & $\begin{array}{c}-2.775 \\
{[1.155]^{* *}}\end{array}$ & $\begin{array}{c}-2.699 \\
{[1.162]^{* *}}\end{array}$ & $\begin{array}{c}-2.646 \\
{[1.199]^{* *}}\end{array}$ & $\begin{array}{c}-2.702 \\
{[1.163]^{* *}}\end{array}$ \\
\hline Union density & $\begin{array}{c}0.003 \\
{[0.008]}\end{array}$ & $\begin{array}{c}0.005 \\
{[0.008]}\end{array}$ & $\begin{array}{c}0.004 \\
{[0.010]}\end{array}$ & $\begin{array}{c}0.006 \\
{[0.009]}\end{array}$ \\
\hline EPL*TURN & $\begin{array}{c}-0.652 \\
{[1.456]}\end{array}$ & & & \\
\hline EPL*EXC & & $\begin{array}{c}-2.752 \\
{[1.264]^{* *}}\end{array}$ & $\begin{array}{c}-2.171 \\
{[1.342]}\end{array}$ & $\begin{array}{c}-2.601 \\
{[1.389]^{*}}\end{array}$ \\
\hline Log (day lost per worker) & & & $\begin{array}{c}-0.034 \\
{[0.258]}\end{array}$ & \\
\hline EPL*DOWN & & & & $\begin{array}{c}-0.899 \\
{[2.792]}\end{array}$ \\
\hline Country by sector dummies & Yes & yes & Yes & Yes \\
\hline Country by year dummies & Yes & yes & Yes & Yes \\
\hline Sector by year dummies & Yes & yes & Yes & Yes \\
\hline Number of observations & 1235 & 1235 & 1121 & 1235 \\
\hline R-squared & 0.93 & 0.94 & 0.94 & 0.94 \\
\hline
\end{tabular}

Note: robust standard errors within brackets. Observations with training participation rates smaller than $0.5 \%$ are excluded. *, **, ***: significant at the $10 \%, 5 \%$ and $1 \%$ level, respectively. 


\section{Conclusions}

Does product market deregulation affect workplace training, and if yes, in what direction? This paper has addressed this question from both the theoretical and empirical viewpoint. Our theory suggests that a relationship between deregulation and training exists, but that its sign is ambiguous. On the one hand, a reduction in the barriers to entry for a given number of firms compresses profits per unit of output, and thereby reduces training. On the other hand, and conditional on profits per unit of output, additional entry increases the output gains from training, which facilitates investment. Our numerical simulations show that for reasonable values of the parameters a negative relationship tends to prevail. Our empirical analysis, based on repeated cross section data extracted the European Labour Force Survey, examines the evidence for a sample of 15 European countries and 13 industrial sectors, which we follow for about 7 years. Our results are unambiguous and show that an increase in product market deregulation generates a sizeable increase in training incidence. These findings highlight that an important link in the relationship between deregulation and productivity growth is the investment in human capital which takes place in firms - or workplace training. 


\section{References}

Acemoglu D and Pischke J (1999), The Structure of Wages and Investment in General Training, Journal of Political Economy, pp. 539-72.

Aghion P, Harris C, Howitt P and Vickers J (2001) Competition, Imitation and Growth with Step-byStep Innovation, Review of Economic Studies 68(3): 467-492.

Aghion P, Bloom N, Blundell R, Griffith R and Howitt P (2005) Competition and Innovation: An Inverted U Relationship, Quarterly Journal of Economics.

Aghion P, Blundell R, Griffith R, Howitt P and Prantl S (2006) The Effects of Entry on Incumbent Innovation and Productivity, mimeo, Harvard University

Alesina A, Ardagna S, Nicoletti S, Schiantarelli F (2005), Regulation and Investment, Journal of the European Economic Association, June, pp.1-35.

Autor D (2004), Why Do Temporary Help Firms Provide Free General Skills?, Quarterly Journal of Economics, MIT Press, vol. 116(4), pp. 1409-1448

Baldwin, R. E., Forslid, R., Haaland, J. (1996) Investment Creation and Diversion in Europe; World Economy, 19, pp. 635-59

Bassanini A, Booth A, Brunello G, De Paola M, Leuven E (2007), Workplace Training in Europe, in Brunello G, Garibaldi P, Wasmer E (eds.), Education and Training in Europe, Oxford University press, Oxford.

Bassanini A, Venn D. (2007), Assessing the impact of labour market policies on productivity: A difference-in-difference approach, mimeo, OECD.

Blanchard O, Giavazzi F (2003), Macroeconomic effects of regulation and deregulation in goods and labor markets, The Quarterly Journal of Economics, 879-907.

Bottasso A., Sembenelli A. (2001) Market power, productivity and the EU Single Market Program: Evidence from a panel of Italian firms, European Economic Review, 45, 167-186.

Brunello G, De Paola M (2007), Training and Economic Density: Evidence from Italian Provinces, Labour Economics, forthcoming

Conti, G. (2005), “Training, Productivity and Wages in Italy”, Labour Economics, vol. 12, no. 4, pp. 557-576.

Conway, P., G. Nicoletti (2006), "Product market regulation in the non-manufacturing sectors of OECD countries: measurement and highlights”, OECD Economics Department Working Paper no. 530. 
Davis, S.J., J.C. Haltiwanger and S. Schuh (1996), Job Creation and Destruction, MIT Press, Cambridge, MA and London

Dearden, L., H. Reed and J. van Reenen (2006), “The Impact of Training on Productivity and Wages: Evidence from British Panel Data”, Oxford Bulletin of Economic and Statistics, vol. 68, no. 4, pp. 397421.

Djankov S, La Porta R, Lopes de Silanes F, Shleifer A (2000), The regulation of entry, The Quarterly Journal of Economics, 1-37

Duso T. and L.H. Röller (2003), Endogenous deregulation: evidence from OECD countries, Economics Letters, 81, 67-71

EC (1997), Single Market Scoreboard, Bruxelles.

EC (1998), Single Market Scoreboard, Bruxelles.

Ebbinghaus B. and J. Visser (2000) Trade Unions in Western Europe since 1945, The Societies of Europe. New York: Grove's Dictionaries.

Gersbach H, Schmutzler A (2001), A product market theory of training, IZA Discussion Paper 327

Gersbach H, Schmutzler A (2006), The Effect of Globalization on Worker Training, IZA Discussion Paper 2403

Gullstrand J., Johansson H. (2005) The Disciplinary Effect of the Single Market on Swedish Firms, Open Economies Review 16: 381-398.

Hall R (2000), Reorganization, Carnegie-Rochester Conference Series on Public Policy, Volume 52, pp. 1-22.

Haltiwanger, J., S. Scarpetta and H. Schweiger (2006), “Assessing Job Flows across Countries: The Role of Industry, Firm Size and Regulations”, IZA Discussion Paper no. 2450

Jovanovic B (2006), Asymmetric Cycles, Review of Economic Studies, 73, 145-162.

Kugler A, Pica G (2004), Effects of Employment Protection and Product Market Regulations on the Italian Labour Market, CEPR Discussion Paper no. 4216.

Malcomson J (1997), Contracts, Holdup and Labor Markets, Journal of Economic Literature, 35, 4, 1916-1957

Micco, A. and C. Pages (2006), "The Economic Effects of Employment Protection: Evidence from International Industry-Level Data”, IZA Discussion Paper no. 2433

Nicoletti G, Scarpetta S (2003), Regulation, productivity and growth: OECD evidence, Economic Policy, pp. 9-72. 
Nicoletti, G., A.Bassanini, E.Ernst, S.Jean, P.Santiago and P.Swaim; (2001) "Product and labour market interactions in OECD countries”, OECD Economics Department Working Paper n³14

OECD (2007), Employment Outlook, Paris, forthcoming.

Schiantarelli F (2005), Product Market Regulation and Macroeconomic Performance: A review of Cross-country Evidence, IZA Discussion Paper.

Sepulveda F (2002), Training and Business Cycles, Michigan State University, mimeo

Stevens M (1996), Transferable Training and Poaching Externalities, in A.L. Booth and D.J. Snower (eds.), Acquiring Skills: Market Failures, Their Symptoms and Policy Responses, Cambridge University Press, Cambridge, UK. 


\section{Appendix}

\section{A. The right-to-manage model}

A popular alternative to the efficient bargain model is the right to manage model, which allocates to the employer the exclusive right to select employment after the parties have bargained over wages. In this Appendix we briefly sketch the equilibrium with right to manage. Further details are available from the authors upon request.

Since employment is set after the bargain, we start from profit maximization net of the training costs, which are sunk. This yields

$$
P_{i}\left(1-\frac{1}{\theta}\right) A[1+(\gamma-1) T]=W_{i} T_{i}+V\left(1-T_{i}\right)
$$

Using this in the Nash maximand [4] and maximizing the outcome with respect to prices, we obtain

$$
P_{i}=\frac{\theta+\beta-1}{(\theta-1)^{2}} \theta \frac{V}{A[1+(\gamma-1) T]}
$$

Replacing [A.1] and [A.2] into ex-ante profits, optimal training is given by

$$
(\theta-1)(\gamma-1)\left[\frac{V(\theta+\beta-1)}{(\theta-1)^{2}}-\frac{\mu T_{i}^{2}}{2}\right]=\mu T_{i}\left[1+(\gamma-1) T_{i}\right]
$$

We add to [A.3] two additional equations, one for the determination of $\mathrm{V}$ in general equilibrium and another for the entry condition

$$
V=\frac{(\theta-1)^{2}}{\theta(\theta+\beta-1)} A[1+(\gamma-1) T]
$$




$$
\Pi=\frac{1}{\theta}-\frac{\mu T^{2}}{2 A[1+(\gamma-1) T]}=\rho
$$

This system of three equations in three unknowns can be further simplified to yield

$$
\begin{aligned}
& \mu T=(\theta-1)(\gamma-1) \rho A \\
& \sigma g(m)=\frac{1}{\rho+\frac{\mu T^{2}}{2 A(1+(\gamma-1) T))}}
\end{aligned}
$$

Inspection suggests that [A.6] is equal to equation [15] and that [A.7] only differs in the numerator on the right hand side. It follows our main Proposition still holds, but that the relevant condition becomes:

$$
\rho>\frac{1}{\theta(\rho)} \frac{\theta(\rho)-1}{\theta(\rho)}
$$

\section{B. The equilibrium when the cost of entry is fixed}

Assume that the cost of entry $R$ is fixed, rather than proportional to output. The two equilibrium conditions become

$$
\begin{aligned}
& \mu T=(\theta-1)(\gamma-1) R \frac{m}{Y} A \\
& \pi=\frac{1-\beta}{\theta}-\frac{\mu T^{2}}{2 A[1+(\gamma-1) T]}=R \frac{m}{Y}
\end{aligned}
$$

We show here that the proposition in the text still holds: total differentiation of [A.9] and [A.10] yields

$$
\begin{aligned}
& \Sigma_{1} d m+\Sigma_{2} d T=\Sigma_{5} d R \\
& \Sigma_{3} d m+\Sigma_{4} d T=\Sigma_{6} d R
\end{aligned}
$$

where 


$$
\begin{array}{lll}
\Sigma_{1}=\sigma g^{\prime}(m)(\gamma-1) m \frac{R}{Y} A+(\sigma g(m)-1)(\gamma-1) \frac{R}{Y} A & \Sigma_{2}=-\mu & \Sigma_{3}=-\frac{1-\beta}{\sigma g(m)^{2}} g^{\prime}(m)-\frac{R}{Y} \\
\Sigma_{4}=-\frac{2 \mu T+\mu T^{2}(\gamma-1)}{2 A[1+(\gamma-1) T]^{2}} & \Sigma_{5}=-(\sigma g(m)-1)(\gamma-1) \frac{m}{Y} A & \Sigma_{6}=\frac{m}{Y}
\end{array}
$$

Since the determinant of the Jacobian is negative when $\theta<+\infty$ and $R>0$, $\frac{d T}{d R}<0$ if $\Sigma_{1} \Sigma_{6}-\Sigma_{3} \Sigma_{5}>0$, that is if

$$
\frac{1-\beta}{\theta(R)} \frac{\theta(R)-1}{\theta(R)} \frac{Y}{m}<R \leq \frac{1-\beta}{\theta(R)} \frac{Y}{m}
$$

Taking into account that $\rho=R \frac{m}{Y}$, eq. [A.11] is equivalent to [16].

We ask now whether, for a given configuration of parameters, deregulation is more likely to increase training when barriers to entry are a fixed costs or when they are proportional to output. First, note that $\max \{R\}=(1-\beta) Y$ and $\max \{\rho\}=1-\beta$. To make things comparable, with no loss of generality, we can assume $Y=1$, which is equivalent to express $R$ as a percentage of the size of the market, so that $\max \{\rho\}=\max \{R\}$. Then define $\hat{\rho}=\sup I_{\rho}$ and $\hat{R}=\sup I_{R}$, where $I_{\rho}=\left\{\rho: \frac{\partial T}{\partial \rho}>0\right\}$ and $I_{R}=\left\{R: \frac{\partial T}{\partial R}>0\right\}$. From [A.11], we have that $\hat{\rho} / \max \{\rho\}=m(\hat{R}) \hat{R} / \max \{R\}>\hat{R} / \max \{R\}$. In other words, when entry costs are fixed deregulation will start reduce training for a smaller value of entry costs relative to their maximum possible value, than in the case when entry costs are proportional to output. If we think in terms of Figure 2, in relative terms, the summit of the bell is even more on the left if fixed entry costs $R$ are on the x-axis.

\section{Choice of parameter values for the numerical simulation}

The median level of the indicator of barriers to entry and vertical integration (BEVI) in the sample of non-manufacturing industries (for which we have direct regulation data) is 3.72. If we divide this number by the maximum possible value of the indicator (which is equal to 6 ) we obtain 0.62 . Since we have no specific prior on $\beta$, it seems natural to assume an even split of the surplus, which implies $\beta=0.5$ and therefore, taking into account that at the sample median $\rho / \max \{\rho\}=0.62$, where $\max \{\rho\}=1-\beta$, we have $\rho=0.62 * 0.5=0.31$. Therefore, we want our choice of parameters to be 
such that the training stock corresponding to $\rho=0.31$ be close to the observed median training stock (0.389). Furthermore, in the sample, the third quartile of the distribution of training stocks in the nonmanufacturing sample is $T_{Q 3}=0.90$. The condition $\mu T^{2} \leq(1-\beta) A(\gamma-1) T$ must hold in the equilibrium, otherwise total training costs to employers will be greater than total benefits. A conservative choice would be to assume that this condition must hold for training stock values below $T_{Q 3}$. This implies $\mu T_{Q 3} \leq 0.5 A(\gamma-1)$. Setting the arbitrary scale parameter $A=1$, this implies that $\mu /(\gamma-1) \leq 0.55$. Setting $\mu=0.1$ and $\gamma=1.2$, we obtain $\mu /(\gamma-1)=0.50$, which is reasonably close to the limit imposed by $T_{Q 3}, A$, and $\beta$. With this choice of parameters, for $\rho=0.31$ we obtain a training stock of 0.361 which is reasonably close to the sample median (0.389).

To show that this choice of parameters yields qualitatively general results, Figures A1, A2 and A3 present the relationship between $T$, $\rho$ and either $\beta, \mu$ or $\gamma$, while keeping all other parameter fixed at benchmark values.

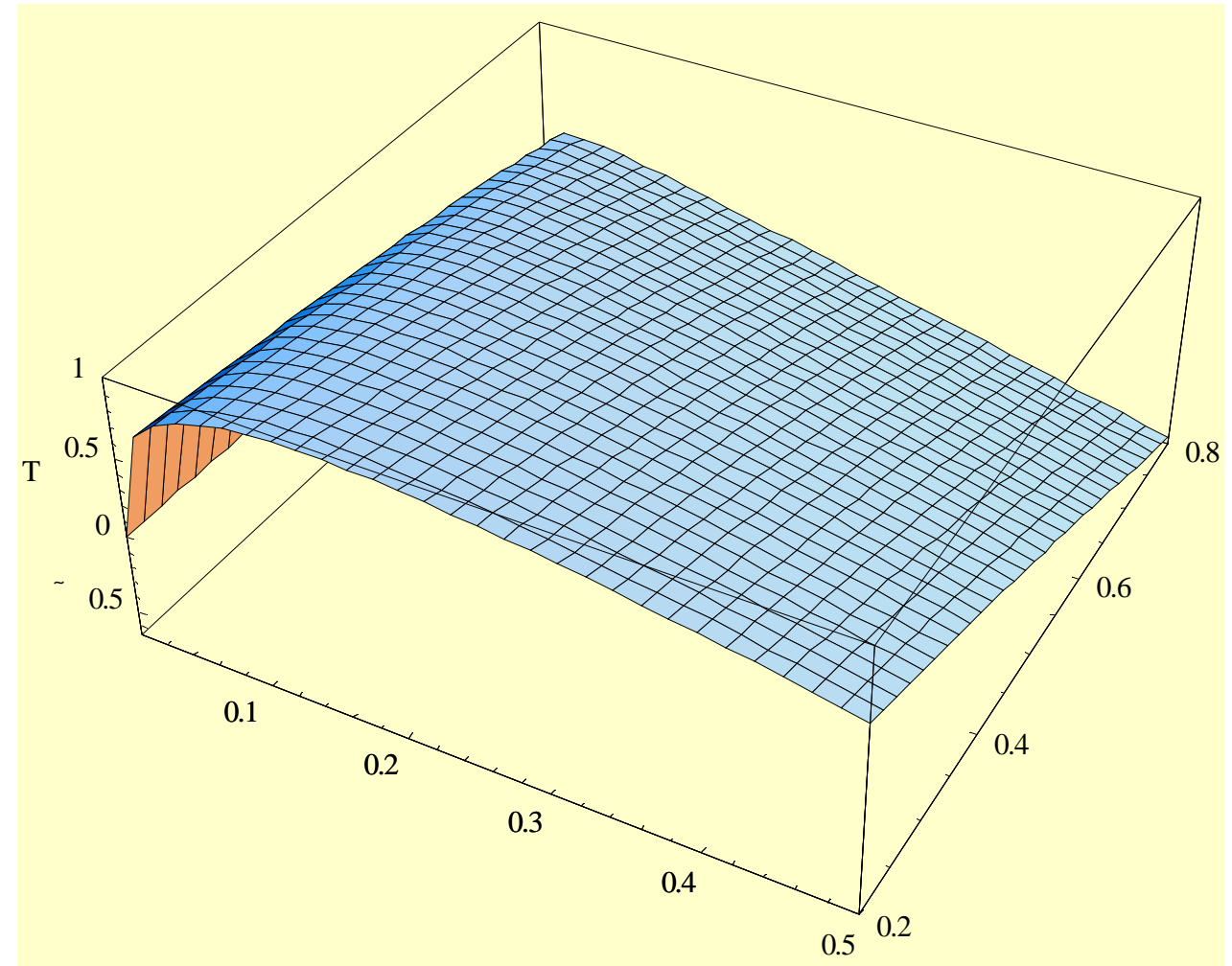

Figure A1: The relationship between $\rho, \beta$ and $T$ with the selected configuration of parameter values. 


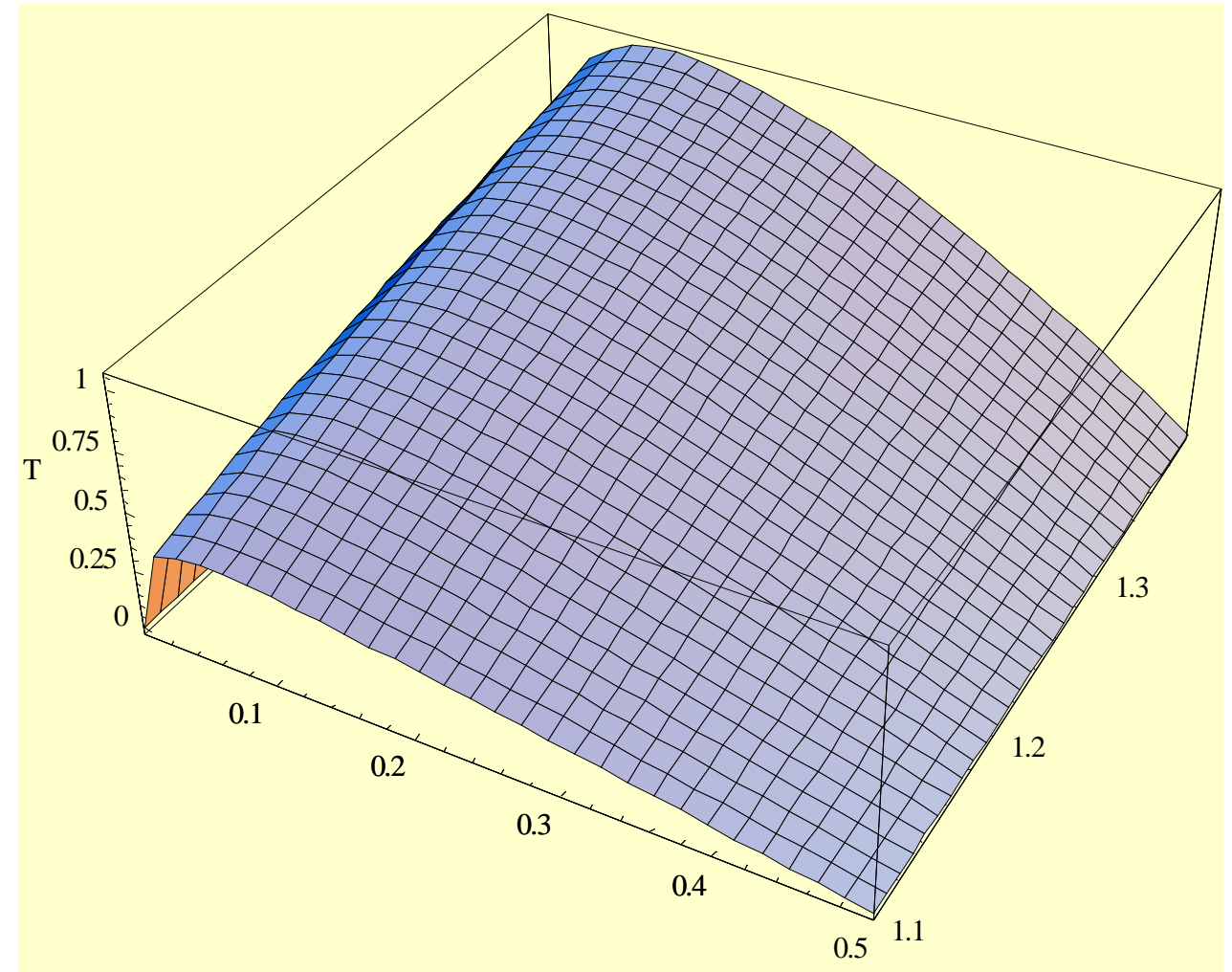

Figure A2: The relationship between $\rho$, $\gamma$ and $T$ with the selected configuration of parameter values.

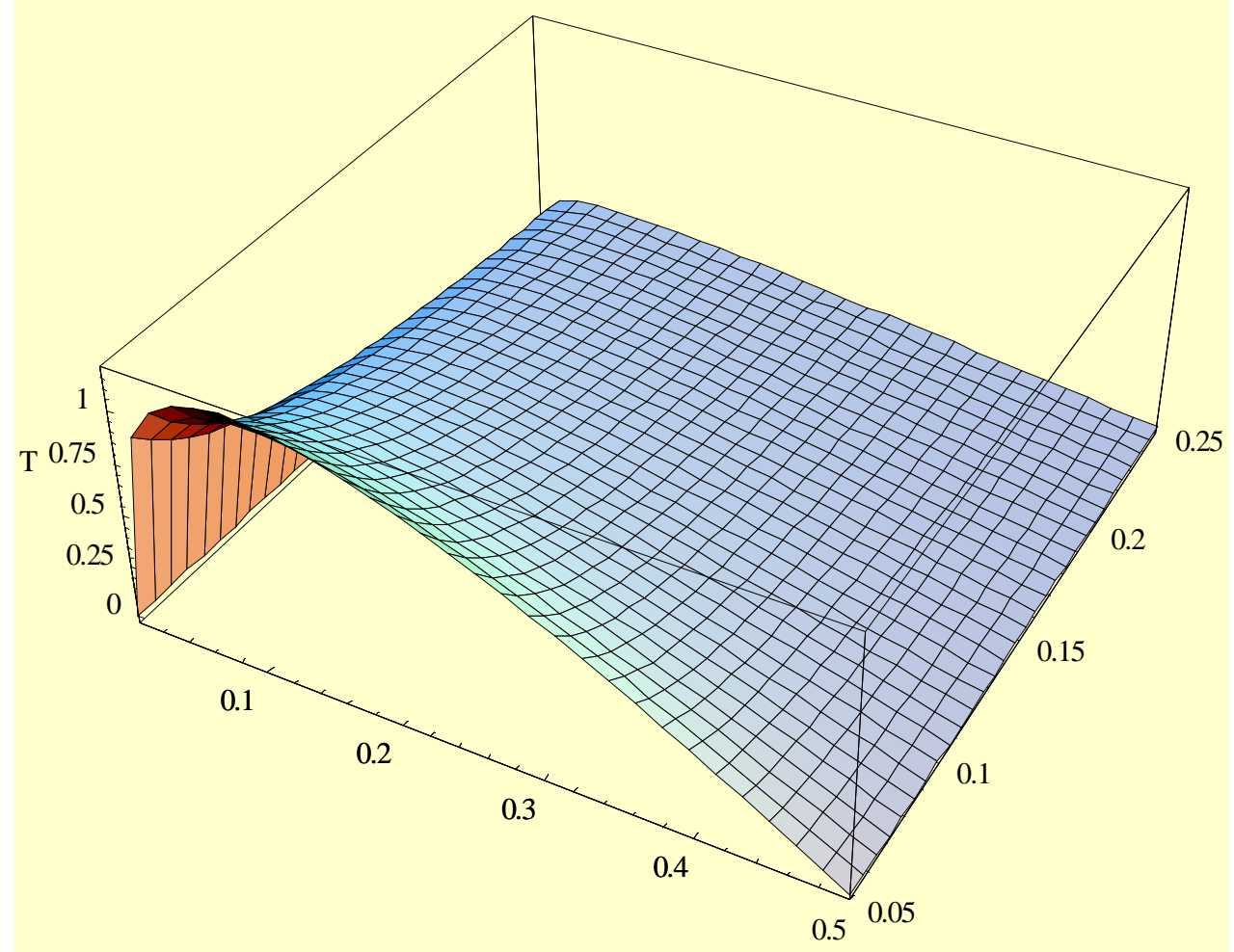

Figure A3: The relationship between $\rho, \mu$ and $T$ with the selected configuration of parameter values. 


\section{Definition of raw variables, sources and descriptive statistics}

\section{Data from the OECD Database on Training}

All variables refer to employees aged between 25 and 54 years working at least 30 hours per week and with at least one month of tenure. Data are derived from Eurostat, European Labour Force Surveys.

\section{Training participation rate}

Definition: Share of employees that took training in the 4 weeks preceding the survey.

Share of males

Definition: ratio of men employees to total wage and salary employment.

\section{Average age}

Definition: average age of employees. Data are available by 5-year classes in the micro-data. Data are aggregated assuming that each individual's age corresponds to the average of each class.

\section{Share low education}

Definition: Share of employees with educational attainment corresponding to ISCED 1-3.

\section{Share medium education}

Definition: Share of employees with educational attainment corresponding to ISCED 4.

Share firms with more than 50 employees

Definition: Ratio of the number employees of firms with more than 50 employees to total wage and salary employment. Since in the microdata, respondents may simply say that firm size is greater than 10 employees, with no distinction between more or less than 50 employees, the share is obtained as the product of the ratio of the number of employees in firms with more than 50 employees to the number of employees in firms with more than 10 employees and the complement to one of the ratio of the number of employees in firms with less than 11 employees to total wage and salary employment.

\section{Data on product market regulation}

All indicators vary from 0 to 6 from least to most restrictive. They are drawn from the OECD Regulatory Database. 
Indicators of sector-specific product market regulation

Definition: Indicators of entry barriers, public ownership, market share of the dominant player(s), vertical integration in network industries and price controls. They cover seven industries (electricity, gas, rail, road freight, air transport, post and telecommunications).

\section{Administrative barriers on start-ups}

Definition: Aggregate concerning administrative barriers for corporations and sole-proprietor firms that apply to all sectors in the economy. Data refer to 1998

\section{Other data}

\section{Employment}

Definition: total persons engaged. Source: Groningen Growth and Development Centre 60-Industry Database.

\section{Hours worked}

Definition: average hours worked per persons engaged. Source: Groningen Growth and Development Centre 60-Industry Database.

\section{Import penetration}

Definition: ratio of imports to value added. Source: OECD STAN Database (current and previous editions).

\section{Labour productivity}

Definition: value added in volume terms (base 100 in 2000) divided by the product of average hours worked and total persons engaged. Source: Groningen Growth and Development Centre 60-Industry Database.

\section{Investment rate}

Definition: ratio of gross fixed capital formation to value added. Source: OECD STAN Database (current and previous editions).

\section{Index of Employment Protection Legislation}

Definition: OECD aggregate summary indicator of the stringency of employment protection legislation incorporating both regular contracts and temporary work. Source: OECD, Employment Outlook 2004.

\section{Union density}

Definition: Share of workers affiliated to a trade union (in \%). Disaggregated data are available only for two macro-sectors Transport and Industry (Manufacturing plus Energy) in Austria, Germany, Italy, the Netherlands, Norway, Spain and Sweden. The macro-sector average is assigned to all subsectors. For the other countries, the same value is assigned to all sectors. Source: Ebbinghaus and Visser (2000).

\section{Days lost for strikes and industrial action}

Definition: Total number of days lost. Disaggregated data are available only for three macro-sectors Transport, Manufacturing and Energy. The macro-sector average is assigned to all subsectors. Source: ILO LABORSTA Database. 


\section{Job creation and destruction rates}

Definition: US average gross job creation and destruction rates aggregated from establishment level data (assuming, for continuous firms, that net employment changes are equal to gross employment changes). Data refer to 1990-1996. Source: Haltiwanger, Scarpetta and Schweiger (2006).

Table A1. List of industries.

\begin{tabular}{|ll|}
\hline NACE Rev. 1 & Description \\
\hline $15-16$ & Food products, beverages and tobacco manufacturing \\
$17-19$ & Textiles, textile products, leather and footwear manufacturing \\
$20-22$ & Wood, pulp, paper and related products manufacturing, printing and publishing \\
$23-24$ & Chemical and fuel products manufacturing \\
$25-26$ & Rubber and plastics and other non-metallic mineral products manufacturing \\
$27-28$ & Basic metals and fabricated metal products manufacturing \\
$30+33$ & Office and computing machinery, medical, optical and precision instruments \\
$34-35$ & Transport equipment manufacturing \\
$29+31+32$ & Other machinery and equipment manufacturing \\
$36-37$ & Recycling and manufacturing not elsewhere classified \\
$40-41$ & Electricity, gas and water supply \\
$60+62$ & Land and air transport \\
64 & Communications services \\
\hline
\end{tabular}

Table A2. Descriptive statistics.

Panel A: Sample of Services + Energy only

\begin{tabular}{|c|c|c|c|}
\hline Variable & Observations & Mean & Standard deviation \\
\hline Training participation rate & 402 & 0.094 & 0.087 \\
\hline Training stock & 402 & 0.581 & 0.548 \\
\hline REGOL & 402 & 3.818 & 1.304 \\
\hline REGNO & 402 & 3.640 & 1.511 \\
\hline BEVI & 402 & 3.556 & 1.667 \\
\hline REGPO & 402 & 4.183 & 1.537 \\
\hline Administrative barriers & 402 & 2.278 & 1.114 \\
\hline Share males & 402 & 0.804 & 0.098 \\
\hline Average age & 402 & 39.84 & 1.34 \\
\hline Share firms with $>50$ employees & 392 & 0.573 & 0.224 \\
\hline Share low education & 387 & 0.329 & 0.193 \\
\hline Share medium education & 387 & 0.495 & 0.174 \\
\hline Hours gap & 402 & 0.001 & 0.012 \\
\hline Employment gap & 402 & -0.002 & 0.038 \\
\hline Employment growth & 402 & -0.004 & 0.041 \\
\hline Union density & 342 & 46.18 & 25.00 \\
\hline EPL*TURN & 402 & 0.380 & 0.204 \\
\hline EPL*EXC & 402 & 0.307 & 0.189 \\
\hline Log (day lost per worker) & 290 & 0.062 & 0.135 \\
\hline EPL*DOWN & 402 & 0.029 & 0.167 \\
\hline
\end{tabular}


Table A2. (continued).

Panel B: Sample of Services, Energy and Manufacturing, post-SMP

\begin{tabular}{|c|c|c|c|}
\hline Variable & Observations & Mean & Standard deviation \\
\hline Training participation rate & 1339 & 0.081 & 0.077 \\
\hline Training stock & 1339 & 0.484 & 0.484 \\
\hline REGOL & 1339 & 0.815 & 1.603 \\
\hline REGNO & 1339 & 0.757 & 1.546 \\
\hline BEVI & 1339 & 0.730 & 1.537 \\
\hline REGPO & 1339 & 0.919 & 1.831 \\
\hline Administrative barriers & 1339 & 2.287 & 1.083 \\
\hline Share males & 1339 & 0.741 & 0.137 \\
\hline Average age & 1339 & 38.73 & 1.56 \\
\hline Share firms with $>50$ employees & 1299 & 0.566 & 0.227 \\
\hline Share low education & 1326 & 0.360 & 0.210 \\
\hline Share medium education & 1326 & 0.461 & 0.175 \\
\hline Log of import penetration & 1326 & 0.304 & 0.792 \\
\hline Hours gap & 1339 & 0.002 & 0.013 \\
\hline Employment gap & 1339 & -0.002 & 0.036 \\
\hline Employment growth & 1339 & 0.000 & 0.040 \\
\hline Union density & 1339 & 44.46 & 24.69 \\
\hline EPL*TURN & 1339 & 0.401 & 0.168 \\
\hline EPL*EXC & 1339 & 0.332 & 0.148 \\
\hline Log (day lost per worker) & 1182 & 0.079 & 0.165 \\
\hline EPL*DOWN & 1339 & 0.002 & 0.053 \\
\hline
\end{tabular}

